\title{
Is centralization a solution to the soft budget constraint problem?
}

\author{
Avi Ben-Bassat ${ }^{\mathrm{a}, 1}$, Momi Dahan ${ }^{\mathrm{b}, 2}$, Esteban F. Klor ${ }^{\mathrm{a}, *, 3}$ \\ a Department of Economics, The Hebrew University of Jerusalem, Mount Scopus, Jerusalem 91905, Israel \\ b Federmann School of Public Policy and Government, The Hebrew University of Jerusalem, Mount Scopus, Jerusalem 91905, Israel
}

\section{A R T I C L E I N F O}

\section{Article history:}

Received 20 September 2015

Received in revised form 19 September 2016

Accepted 21 September 2016

Available online 23 September 2016

\section{JEL codes:}

D82

H77

\section{Keywords:}

Soft budget constraints

Centralization

Local government

Bailout program

Hierarchical subordination

Political institutions

\begin{abstract}
A B S T R A C T
This paper focuses on the centralization program implemented in Israel in 2004 to analyze whether the administrative subordination of municipalities is an effective policy to deal with problems related to soft-budget constraint of lower level governments. The results consistently show, for different specifications and samples of municipalities, that this program brought a substantial decrease of municipalities' expenditures (mostly because of decreases in salary payments), and an increase of local property tax collection. Our analysis shows that all of the fiscal impact of the program is due to the appointment of an accountant that reports directly to the central government, a relatively mild form of administrative subordination. In contrast, more intrusive forms of subordination, like the central imposition of a recovery program, do not result in any substantial improvement of municipalities' fiscal situation. This leads us to conclude that a mild form of administrative subordination is an effective tool to cope with problems related to soft-budget constraints, whereas political subordination is not an effective tool to reach that goal.
\end{abstract}

(c) 2016 Elsevier B.V. All rights reserved.

\section{Introduction}

Whereas the last decades of the 20th century brought about a large wave of fiscal decentralization in countries around the world, we observe in the last few years a move on the opposite direction. Currently, central governments tend to intervene and constraint the behavior of local governments in developed and developing countries. There is a growing body of evidence showing such a trend in developed economies like England (Turner and Whitman, 2005), Germany (Rodden, 2006), Italy (Bordignon, 2013), and the U.S. (Inman, 2003), and in a large number of developing countries like Argentina (Webb, 2003), Brazil (Rodden, 2006), China (Yee, 2012), Hungary (Wetzel and Papp, 2003), India (McCarten, 2003), and Russia (Zhuravskaya, 2010), just to name a few examples. The recent global downturn strengthened the move towards further centralization and administrative subordination of local authorities in Europe and the U.S. (Viver Pi-Sunyer and Martín, 2013).

The move to centralization takes different forms across countries. For example, Putin started centralizing Russia's local governments as soon as he assumed power. He cancelled regional elections for governors in 2005. Since then, Russia's president person-

\footnotetext{
* Corresponding author.

E-mail addresses: avibb@huji.ac.il (A. Ben-Bassat), momidahan@mscc.huji.ac.il (M. Dahan), eklor@huji.ac.il (E.F. Klor).

1 Hebrew University and College of Management Academic Studies.

2 Hebrew University and IDI.

${ }^{3}$ Hebrew University and CEPR.
} 
ally appoints professional representatives of the central government as governors and heads of regional legislatures (Zhuravskaya, 2010). There are also examples with less intrusive methods of centralization. As stated in Wetzel and Papp (2003), Hungary put in place legislation to regulate local governments that declare themselves insolvent or in bankruptcy. Accordingly, the law states that localities in dire financial situations are solely responsible to pay their debts. In addition, the central government names a financial trustee to monitor the functioning of the municipality and to ensure that an emergency budget is implemented. Argentina's case provides a more moderate example. According to Webb (2003), the Argentinean federal government made available a program of debt relief or debt rescheduling to provinces, contingent on the provinces implementing reform programs.

The original drive for decentralization posited that lower level governments tend to make more efficient decisions over local public revenues and expenditures for a number of reasons. First, due to inter-jurisdictional competition, local politicians have a strong incentive to provide better services to attract more residents (Tiebout, 1956; Besley and Case, 1995). In addition, local politicians are more attune with the preferences of the local population and better informed of their needs and capabilities. Finally, individuals may be able to sort themselves across localities based on their preferences and the characteristics of each locality (Oates, 1972). Hence, the argument goes, when local politicians serve their constituency, transferring decision-making to the local level should lead to policies that better reflect the residents' needs and preferences, and may also increase efficiency if inter-jurisdictional externalities and economies of scale are not too severe.

Paradoxically, it turns out that local politicians' willingness to cater exclusively to their constituencies became one of the main problems of decentralization. In their drive to satisfy their electorate, local politicians face strong incentives to engage in opportunistic behavior, whereby they shift part of the financial burden associated with local provision of services to higher levels (Klor, 2006). That is, when the central government tends to bailout localities in financial distress, localities that repeatedly deviate from balanced budget constraints are able to extract transfers from others, more financially responsible localities. Hence, a commonpool practice behind the financing of local expenditures creates strong incentives for local officials to overspend. This is known in the literature as the soft-budget constraint problem following the seminal work of Kornai (1979). ${ }^{4}$

The central government has a direct way of dealing with soft-budget constraint problems. This includes developing an institutional setting that imposes the right incentives on local governments such as a credible no-bailout policy. In most countries, however, central governments are unable to commit to a no-bailout policy for political reasons (Quian and Roland, 1998). In these cases, central governments tend to resort to hierarchical oversight and regulation to reign on localities' spending and impose on them hard budget constraints. These types of interventions, also called administrative subordination, often consist of centrally appointing local officials rather than electing them.

This paper studies whether administrative subordination is an effective tool to cope with soft-budget constraint problems without affecting the local provision of public goods. For these purposes we focus on a major centralization program implemented in Israel in 2004. According to this program, the central government in Israel uses three types of interventions on local governments. They consist of imposing different degrees of administrative subordination of local politicians to the central government. Within the framework of this program, the central government is entitled to (i) appoint an accountant that has to approve every expenditure of the municipality and reports directly to the central government; (ii) impose a recovery program specifically tailored for each municipality that specifies, among other things, tax collection targets and number of employees that need to be fired; and (iii) dismiss the mayor and members of the municipal council and replace them by a summoned board as the only authority of the municipality. Since their inception, these programs were instituted in more than half of Israel's municipalities in order to curtail their deficits and expenditures.

Despite the widespread use of hierarchical oversight and administrative subordination in Israel and elsewhere there is not, to the best of our knowledge, definite empirical evidence testing the effectiveness of hierarchical oversight on solving the softbudget constraint problem. Some researchers claim that hierarchical administrative controls are effective in imposing a hard budget constraint in decentralized OECD countries like Canada (Bird and Tassonyi, 2003) and Norway (Rattsø, 2003). Others argue that this approach does not seem to be effective in developing countries like Argentina (Webb, 2003), India (McCarten, 2003), and Russia (Zhuravskaya, 2010). The studies above base their conclusions on a descriptive approach, and do not present systematic empirical evidence trying to estimate the causal effect of hierarchical subordination on the outcomes of interest. The evidence is not conclusive either when looking at cross-countries analyses. Enikolopov and Zhuravskaya (2007) show that administrative subordination does not lead to better economic outcomes using a sample of 75 developing countries. Rodden (2002) finds that restrictions imposed on subnational governments by the central government lead to better fiscal performances using a similar sample of 43 developing countries.

This paper focuses on the widespread use of hierarchical oversight and administrative subordination in Israel since 2004 to analyze their effects on municipalities' fiscal performance and their provision of public goods. The analysis is based on an original detailed panel data set containing all the relevant characteristics of the municipalities between 2000 and 2010 . This allows us to control for municipality fixed effects and aggregate years effects, thus identifying the effects of central intervention on the variation of outcome variables of interest across municipalities over time.

\footnotetext{
${ }^{4}$ Kornai's (1979) contribution started a large and growing literature analyzing the causes and consequences of soft-budget constraints. See Kornai et al. (2003) for a theoretical analysis of soft-budget constraints and a review of the related literature not only covering the framework of local governments, but including applications related to the banking system, other private firms, and nonprofit organizations, just to name a few. See Prud'homme (1995) and Tanzi (1996) for early warnings on the risks associated with fiscal decentralization due to the existence of soft-budget constraints. Pettersson-Lidbom (2010) and Bordignon and Turati (2009) present empirical evidence on the consequences of soft-budget constraints based on Swedish localities and Italian regions, respectively.
} 
The results of the analysis show that the administrative subordination of local politicians has had a significant effect on municipalities' fiscal performance. Focusing on the entire sample of municipalities we find that centralization has a substantial impact on several key fiscal outcomes such as the municipality's deficit, debt, total expenditures, total wage bill and local tax collection. There is a reasonable concern, however, that these results are spurious, most likely caused by time varying unobservable differences between treated and untreated municipalities (in addition, the pre-treatment trends for municipalities' deficit and debt are not parallel). We perform several analyses to alleviate these concerns. First, in the spirit of a regression discontinuity approach, we base our analysis only on municipalities in the neighborhood of the predetermined threshold for intervention. This gives us a sample of similar municipalities in terms of their observable pre-treatment characteristics. These estimations confirm the conclusions reached when looking at the entire sample of municipalities. While the effects of intervention are not immediate on municipalities' deficit and debt, every additional year under central intervention causes a significant decrease of 1.9 percent on total expenditures (mostly due to a decrease on total salary payments). Given that the average duration of intervention for intervened municipalities equals 5 years, these magnitudes imply an overall decrease of 9.5 percent on total expenditures. The fiscal improvements of municipalities under intervention do not seem to have a significant effect on their residents' welfare, at least when measured by their residents' educational achievements, out-migration, and the number of car accidents (Ben-Bassat et al., 2013).

We decompose the effects of intervention between the different types of administrative subordination enacted by the central government. The analysis shows that all of the significant effects are due to the appointment of an accountant that reports directly to the central government. The only significant effect of a recovery program is a substantial increase of transfers from the central government. Hence, our analysis concludes that the effects of central intervention on municipalities' fiscal performance can be achieved under limited intervention, which is more desirable than more intrusive forms of centralization of local governments.

There are several mechanisms behind the impact of appointed accountants found in our study. First, centrally appointed accounts have veto power over the municipalities' expenses. In addition, appointed accountants play a crucial role by providing reliable information on municipalities' performance to the Interior Ministry. Based on this information, the central government in Israel tends to condition the transfer of funds in return for fiscal discipline. For example, Baskaran et al. (2015) show that centrally appointed accountants prevent Israeli municipalities from incurring in political budget cycles (i.e., increasing their deficits during electoral years).

Unlike appointed accountants and summoned committees, which were completely determined by the Interior Ministry, the institution of a recovery plan was, to a certain extent, the result of negotiations between local elected officials and the Interior Ministry. That discretion, together with asymmetric information (for municipalities without a centrally appointed accountant) seems to allow some municipalities to deviate from predetermined fiscal targets set by the Interior Ministry. This ultimately undermines the impact of recovery programs when implemented without the added supervision of an appointed accountant. Related studies find similar results in other contexts (see, e.g., Dietrichson and Ellegård, 2015).

Summarizing, the analysis shows that the program may have affected the municipalities' expectations of receiving funds from the central government without paying a political cost. Therefore, the intervention program effectively curbed the incentives of local politicians to overspend, giving the central government an effective tool to cope with municipalities' soft-budget constraint problem.

\section{Institutional and fiscal background}

Over the last two decades, the fiscal performance of Israel's municipalities has been characterized by repeated crises, which resulted in severe service interruptions both at the local and national level. Usually, the central government intervened and solved the conflict by bailing-out municipalities in financial difficulties. For example, the central government covered the municipalities' deficits in 1989, 1992, 1994-1995, 1996 and 1997. Although these transfers from the central government were able to temporarily solve the financial problems of Israeli municipalities, they de-facto imposed a system of soft budgets constraints. Accordingly, the central government would come to the rescue of municipalities unable to cover their deficits. ${ }^{5}$

The lack of commitment of the central government not to bail out troubled municipalities was evident until the mid 1990s. The repeated bailouts had a pervasive effect not only on the incentives of municipalities' mayors. Even voters understood the prevailing incentives that mayors faced and tended to reward at the polls mayors that increased local expenditures and deficits before the elections (Rosenberg, 1992). ${ }^{6}$

After repeated bailouts and transfers during the 1990s, the central government reached the conclusion that one of the main causes for the constant fiscal failure of municipalities was the central governments' behavior and the pernicious incentives that behavior created. In part to solve the problem created by the soft budget constraints, and in part because of the economic impact of the global economic crisis and the Second Palestinian uprising, the central government substantially lowered its transfers to

\footnotetext{
${ }^{5}$ According to Kornai et al. (2003), a sub-central government has a soft budget constraint when it issues debt to cover its deficits with the expectation of receiving funds or grants from the central government. This definition is widely used in the related literature (see, e.g., Sorribas-Navarro, 2011). Note that our analysis does not directly measure the effects of the new policy on soft-budget constraint considerations because we don't directly measure the expectations of sub-central governments regarding future bailouts. We take the pervasive incentives created by soft-budget constraints as given and show that the policy change brought about a decrease in spending. This is only suggestive evidence of a change on expectations of future bailouts.

${ }^{6}$ See also the results of Brender (2003), who claims that the electorate did not punish fiscally irresponsible mayors in the local elections of 1989 and 1993 . Brender (2003) shows, however, that as a consequence of the enforcement of audit and financial reporting of localities' budgets enacted in 1994, the electorate voted out of office fiscally irresponsible mayors in the local elections of 1998.
} 
municipalities between 2001 and 2003. As a consequence, a large number of municipalities suffered a severe economic crisis, their debts and deficits ballooned and the quality of services they provided deteriorated (Ben-Bassat and Dahan, 2009).

Unwilling to increase its transfers to municipalities and bail them out, the Israeli central government decided in 2003 to implement several new measures regarding its dealings with local governments. The main objective of these measures was to restore the budget discipline of local governments. These measures consisted on different types of central intervention on local governments to ensure that municipalities do not deviate from pre-determined fiscal objectives. As stated above, since 2004 the central government in Israel uses three types of policies of administrative subordination of local governments. In an increasing order of centralization, these policies consist on (i) the appointment of an accountant; (ii) the imposition of a recovery program, and/or (iii) dismissing the mayor and members of the local council while imposing a summoned board as the main authority of the municipality. ${ }^{7}$

The level of intrusiveness of the central government, and the corresponding damage to local democratic institutions, gradually increases as we move from an intervention of type (i) to an intervention of type (iii). The first type of intervention, the appointment of an accountant that reports directly to the Interior Ministry, is meant to provide the central government with direct control over a municipality's expenditures. The appointed accountant has to approve in advance every expense of the municipality, including the hiring of new employees. In some municipalities, the appointed accountant (or a different functionary under the accountant's responsibility) is also in charge of collecting local property taxes.

The second type of intervention consists of the formulation of a recovery program for the municipality under intervention. While in the past municipalities that received "recovery payments" from the central government to cover their deficits were said to be in a "recovery program," there were no clear guidelines or objectives to be fulfilled under this program. This situation drastically changed with the new program that the government approved in 2003 and started in 2004 . As of 2004 the typical recovery program includes a carrot and a stick. It is clearly specified in a municipality's recovery program that it must achieve a balanced budget within a certain period of time. In addition, the program details the types of expenditures that must be cut, the number of workers that must be fired in each area (e.g. education and welfare), and the expected increase in local tax collection. As part of the agreement between the central government and the municipality, the Interior Ministry rewards municipalities that meet the recovery program's targets with transfers that equal half of their short-term debt ( $50 \%$ as a grant and the remainder $50 \%$ as a loan).

The final type of intervention is the imposition of a summoned board. This is the most severe measure of administrative subordination taken to deal with the fiscal crisis of some municipalities. The central government replaces by decree the municipality's elected officials (the mayor and the members of the local council) by a summoned committee. Once in place, all roles and responsibilities are transferred from the elected mayor to the appointed committee. The committee then governs the municipality up until the next local election, which is usually three years after the appointment of the committee. In some cases, under the discretion of the central government, a committee may be appointed to two terms of three years each.

In short, the centralization program of 2004 introduced two main changes to the previous practice used for the central funding of municipalities in Israel. The first main change is that from 2004 onwards the government's recovery payments to municipalities are conditional on the municipality achieving pre-determined fiscal goals. The second main change implemented in 2004 is the introduction of clear rules determining the criteria used to intervene in municipalities, and the type of administrative subordination chosen for municipalities under intervention. During the previous regime the Interior Ministry had the authorization (but not the duty) to intervene when locally elected officials did not administer the municipality's budget in a responsible manner, where "responsible manner" was stated in vague terms and left to the eye of the beholder. The plan implemented in 2004 does not longer rely on vague definitions and interpretations. Instead, the new rules use clear definitions on objective and measurable outcomes to determine the type of intervention required on each municipality. These criteria are outlined in Table 1.

Accordingly, the Interior Ministry appoints an accountant to municipalities whose current deficit as a share of their total revenue is above 10 percent and whose short-term debt is above 15 percent of total revenue. In addition, for the central government to be able to appoint an accountant it has to be the case that the municipality underperforms with respect to its local tax collection. The exact thresholds for underperforming regarding tax collection vary according to municipalities socio-economic index. ${ }^{8}$

For municipalities in a worse fiscal situation the Interior Ministry may impose on them a specially tailored recovery program. Such a program is prepared for municipalities whose short-term debt is above 17.5 percent of its total revenue. Recovery programs were also restricted to municipalities that were entitled to (unconditional) equalization grants and with more than 4000 residents. ${ }^{9}$ In addition to a recovery program, the Interior Ministry appoints an accountant to some municipalities if it considers that they are not going to properly execute the requirements outlined in their recovery program. Indeed, during the period at issue many municipalities are under both types of intervention: they have an accountant appointed by the Interior Ministry and are under a recovery program.

\footnotetext{
${ }^{7}$ In addition to these types of intervention, in 2003 the central government imposed the amalgamation of 27 localities into 13 localities and regional councils. The main objective of this policy was to take advantage of economies of scale in the provision of local public services. See Reingewertz (2012) for an analysis on the effects of this policy on the amalgamated localities' fiscal performance.

${ }^{8}$ Every municipality in Israel is ranked by its socio-economic status according to a scale from 1 (the lowest status) to 10 (the highest status). The rank is based on the municipalities residents' standard of living (income per capita, average age of car, share of new cars), education level (share of residents that completed their matriculation, share of students), demographic composition (median age, dependency ratio, share of families with four children or more), employment (unemployment rate, share of workers earning salaries at or below the minimum wage, share of workers who earn more than twice the average wage), and welfare benefits (recipients of unemployment benefits, income support and old age income support).

9 A municipality is entitled to an equalization grant if the minimum expenditure required to provide basic local services is higher than the municipality's potential revenue. In 2007, 231 out of 252 localities received equalization grants. The size of the minimum expenditures, and as a result the amount of the grant, depends on several of the locality's characteristics. The grants increase with population size, with demographic dependency ratio, and with type of locality (regional councils receive higher grants). These grants decrease with the localities' socio-economic status. Up until 2007, localities in priority areas received higher equalization grants but the Supreme Court stopped this practice by declaring it illegal.
} 
Table 1

Criteria for Inclusion of Municipalities on Intervention Program.

\begin{tabular}{|c|c|c|c|c|c|}
\hline & \multirow{2}{*}{ Current Deficit (as a share of Total Revenue) } & \multirow{2}{*}{ Short Term Debt (as a share of Total Revenue) } & \multicolumn{3}{|c|}{$\begin{array}{l}\text { Local Tax Collection (by } \\
\text { Socio-Economic Index) }\end{array}$} \\
\hline & & & $1-4$ & $5-7$ & $8-10$ \\
\hline \multicolumn{6}{|l|}{ Type of Intervention: } \\
\hline - Accountant & Over $10 \%$ & Over $15 \%$ & $50 \%$ & $55 \%$ & $60 \%$ \\
\hline - Recovery Program & & Between $17.5 \%$ and $50 \%$ & - & - & - \\
\hline - Summoned Board & Over $15 \%$ & Over 30\% & $40 \%$ & $50 \%$ & $60 \%$ \\
\hline
\end{tabular}

Notes: Information obtained from the Israeli Ministry of Interior.

- The rates of tax collection specified in the table regarding the imposition of an accountant refer to collection of water and local property taxes.

- The rates of tax collection specified in the table regarding the imposition of a summoned board refer to local property taxes. In addition, a summoned board is imposed if the collection of water bills is below $70 \%$.

- The central government can impose a summoned board also if the local budget has not been approved at the local council within three months after the beginning of the fiscal year.

- When the short-term debt as a share of total revenue of a municipality exceeds $50 \%$ the municipality is forced to restructure its debt in the framework of an agreement with its creditors.

Table 2

Number of Local Governments under Central Intervention (by Type of Intervention), 2004-2010.

\begin{tabular}{|c|c|c|c|c|c|c|c|}
\hline & 2004 & 2005 & 2006 & 2007 & 2008 & 2009 & 2010 \\
\hline Accountant & 30 & 38 & 51 & 76 & 75 & 73 & 72 \\
\hline Recovery Program & 113 & 107 & 70 & 73 & 50 & 30 & 15 \\
\hline Summoned Boards & 0 & 4 & 9 & 25 & 27 & 25 & 25 \\
\hline Localities under intervention & 115 & 109 & 90 & 99 & 85 & 82 & 80 \\
\hline \multicolumn{8}{|l|}{ Duration of Intervention: } \\
\hline-1 year & 115 & 5 & 4 & 3 & 1 & 2 & 3 \\
\hline-2 years & & 104 & 8 & 7 & 1 & 0 & 2 \\
\hline-3 years & & & 78 & 19 & 6 & 4 & 1 \\
\hline-4 years & & & & 70 & 15 & 6 & 2 \\
\hline-5 years & & & & & 62 & 12 & 6 \\
\hline-6 years & & & & & & 58 & 11 \\
\hline-7 years & & & & & & & 55 \\
\hline
\end{tabular}

Note: There were not any interventions between 2000 and 2003. During the years 2004-2010 there were in Israel 193 municipalities. Notice that some municipalities may have more than one type of intervention at any given year.

A municipality has to be even under a direr fiscal situation for a summoned board to be imposed. Summoned boards are imposed on municipalities whose current deficit is over 15 percent of their total revenue, whose short-term debt is over 30 percent of their total revenue, and whose tax collection rates are below the thresholds specified in Table 1 . In addition, the ministry of interior must dismiss a municipality's elected bodies and impose a summoned board when its council has not approved the municipality's budget within three months after the beginning of the fiscal year. ${ }^{10}$

\section{Data}

For the purposes of our analysis we use data on central intervention and on economic and demographic characteristics of municipalities in Israel between 2000 and 2010. The data on central interventions come directly from the Interior Ministry. The data on economic and demographic characteristics of the municipalities come from the Israeli Central Bureau of Statistics (ICBS). Yet, the actual source of these data is also the Interior Ministry, which aggregates the municipalities' financial reports after their approval and submits them to the ICBS.

\footnotetext{
${ }^{10}$ Summoned boards were sparingly imposed since the creation of Israel in 1948. Before the intervention program of 2004, this type of intervention was almost exclusively used in cases where the municipality's mayor was removed from office and under criminal investigation on accusations of corrupt behavior. There were 6 municipalities intervened by a summoned board between 1990 and 1999. Four municipalities were under this type of intervention between 2000 and 2003 . Removing these municipalities from the analysis does not affect any of the results of this paper.
} 
Table 3

Summary Statistics on Municipalities' Outcomes of Interest-Entire Sample.

\begin{tabular}{|c|c|c|c|c|c|c|c|c|c|c|}
\hline & \multicolumn{2}{|l|}{$2000-2003$} & \multicolumn{2}{|l|}{$2004-2010$} & \multicolumn{4}{|c|}{ Treated Minus Control } & \multirow{2}{*}{\multicolumn{2}{|c|}{ Diffs-in-Diffs }} \\
\hline & $\begin{array}{l}\text { Intervened } \\
\text { during } \\
2004-2010\end{array}$ & $\begin{array}{l}\text { Not Intervened } \\
\text { during 2004-2010 }\end{array}$ & $\begin{array}{l}\text { Intervened } \\
\text { during } \\
2004-2010\end{array}$ & $\begin{array}{l}\text { Not Intervened } \\
\text { during 2004-2010 }\end{array}$ & \multicolumn{2}{|l|}{ 2000-2003 } & \multicolumn{2}{|l|}{ 2004-2010 } & & \\
\hline & $(1)$ & $(2)$ & $(3)$ & $(4)$ & $(5)$ & & $(6)$ & & \multicolumn{2}{|l|}{$(7)$} \\
\hline \multicolumn{11}{|l|}{ Outcomes of Interest } \\
\hline $\begin{array}{l}\text { A. Final Goals } \\
\text { - Deficit (NIS per capita) }\end{array}$ & $\begin{array}{l}545 \\
(546)\end{array}$ & $\begin{array}{l}118 \\
(208)\end{array}$ & $\begin{array}{l}342 \\
(598)\end{array}$ & $\begin{array}{l}74 \\
(291)\end{array}$ & $\begin{array}{l}426.68 \\
{[38.20]}\end{array}$ & $* * *$ & $\begin{array}{l}268.14 \\
{[36.07]}\end{array}$ & $* * *$ & $\begin{array}{l}-158.55 \\
{[38.58]}\end{array}$ & $* * *$ \\
\hline $\begin{array}{l}\text { - Short Term Debt as a } \\
\text { share of Total Revenue }\end{array}$ & $\begin{array}{l}0.285 \\
(0.233)\end{array}$ & $\begin{array}{l}0.113 \\
(0.158)\end{array}$ & $\begin{array}{l}0.340 \\
(0.320)\end{array}$ & $\begin{array}{l}0.105 \\
(0.140)\end{array}$ & $\begin{array}{l}0.172 \\
{[0.027]}\end{array}$ & $* * *$ & $\begin{array}{l}0.235 \\
{[0.025]}\end{array}$ & $* * *$ & $\begin{array}{l}0.064 \\
{[0.025]}\end{array}$ & $* * *$ \\
\hline $\begin{array}{l}\text { - Total Economic } \\
\text { Expenditures (NIS per } \\
\text { capita) }\end{array}$ & (1463) & (1121) & (1250) & (1439) & -417.08 & $* *$ & -845.85 & $* * *$ & -428.78 & $* * *$ \\
\hline $\begin{array}{l}\text { B. Fiscal Instruments } \\
\text { - Total Salary Payments } \\
\text { (NIS per capita) }\end{array}$ & $\begin{array}{l}1859 \\
(585)\end{array}$ & $\begin{array}{l}1914 \\
(542)\end{array}$ & $\begin{array}{l}1710 \\
(529)\end{array}$ & $\begin{array}{l}1924 \\
(619)\end{array}$ & $\begin{array}{l}-54.49 \\
{[84.69]}\end{array}$ & & $\begin{array}{l}-213.48 \\
{[88.79]}\end{array}$ & $* * *$ & $\begin{array}{l}-158.99 \\
{[41.52]}\end{array}$ & **** \\
\hline $\begin{array}{l}\text { - Share of Local Property } \\
\text { Taxes Collected }\end{array}$ & $\begin{array}{l}0.405 \\
(0.242)\end{array}$ & $\begin{array}{l}0.645 \\
(0.212)\end{array}$ & $\begin{array}{l}0.379 \\
(0.221)\end{array}$ & $\begin{array}{l}0.607 \\
(0.215)\end{array}$ & $\begin{array}{l}-0.240 \\
{[0.034]}\end{array}$ & $* * *$ & $\begin{array}{l}-0.228 \\
{[0.033]}\end{array}$ & $* * *$ & $\begin{array}{l}0.011 \\
{[0.012]}\end{array}$ & \\
\hline $\begin{array}{l}\text { - Recovery Payments (NIS } \\
\text { per Capita) }\end{array}$ & $\begin{array}{l}110 \\
(224)\end{array}$ & $\begin{array}{l}15 \\
(61)\end{array}$ & $\begin{array}{l}223 \\
(355)\end{array}$ & $\begin{array}{l}8 \\
(44)\end{array}$ & $\begin{array}{l}95.24 \\
{[13.84]}\end{array}$ & $* * *$ & $\begin{array}{l}215.74 \\
{[19.29]}\end{array}$ & $* * *$ & $\begin{array}{l}120.51 \\
{[18.02]}\end{array}$ & $* * *$ \\
\hline $\begin{array}{l}\text { - Equalization Grants (NIS } \\
\text { per capita) }\end{array}$ & $\begin{array}{l}1275 \\
(801)\end{array}$ & $\begin{array}{l}906 \\
(815)\end{array}$ & $\begin{array}{l}948 \\
(601)\end{array}$ & $\begin{array}{l}621 \\
(624)\end{array}$ & $\begin{array}{l}368.48 \\
{[128.64]}\end{array}$ & $* * *$ & $\begin{array}{l}327.63 \\
{[100.17]}\end{array}$ & $* * *$ & $\begin{array}{l}-40.85 \\
{[67.07]}\end{array}$ & \\
\hline \multicolumn{11}{|l|}{$\begin{array}{l}\text { C. Control Variables of } \\
\text { Interest }\end{array}$} \\
\hline $\begin{array}{l}\text { - Population Size (in } \\
\text { thousands) }\end{array}$ & $(62)$ & $(72)$ & $(68)$ & $(76)$ & {$[10.75]$} & & {$[11.490]$} & & {$[1.006]$} & \\
\hline - Socio-Economic Status & $\begin{array}{l}4.102 \\
(2.040)\end{array}$ & $\begin{array}{l}5.992 \\
(2.327)\end{array}$ & $\begin{array}{l}4.148 \\
(1.994)\end{array}$ & $\begin{array}{l}6.100 \\
(2.274)\end{array}$ & $\begin{array}{c}-1.889 \\
{[0.348]}\end{array}$ & $* * *$ & $\begin{array}{l}-1.952 \\
{[0.339]}\end{array}$ & $* * *$ & $\begin{array}{l}-0.063 \\
{[0.057]}\end{array}$ & \\
\hline $\begin{array}{l}\text { - Share of Largest Party in } \\
\text { Municipal Council }\end{array}$ & $\begin{array}{l}0.288 \\
(0.147)\end{array}$ & $\begin{array}{l}0.381 \\
(0.207)\end{array}$ & $\begin{array}{l}0.287 \\
(0.144)\end{array}$ & $\begin{array}{l}0.355 \\
(0.175)\end{array}$ & $\begin{array}{l}-0.093 \\
{[0.029]}\end{array}$ & $* * *$ & $\begin{array}{l}-0.069 \\
{[0.023]}\end{array}$ & $* * *$ & $\begin{array}{l}0.025 \\
{[0.021]}\end{array}$ & \\
\hline
\end{tabular}

Notes: Data from ICBS. The numbers on each cell are the means of the respective variable listed on the left column. Standard deviations appear in parentheses in columns (1) to (4). Standard errors appear in brackets in columns (5), (6) and (7). *, **, and *** represent statistical significance at $10 \%, 5 \%$, and $1 \%$ levels.

\subsection{Data on extent and types of municipalities' administrative subordination}

Table 2 depicts the data on the type and extent of central intervention on localities. The table reports all interventions in municipalities (cities with more than 20,000 residents) and local councils (usually smaller towns) in Israel from the beginning of the intervention program in 2004 until 2010. ${ }^{11}$ The table shows that the move from a regime with a lot of discretion to one with clear and objective rules resulted in a substantial increase in the number of municipalities under intervention. For example, we see that in 2004, the first year of the new program, almost 60 percent of the localities were under intervention, an overwhelming majority of them under a recovery program. This shows the commitment of the central government to implementing the reform intended to generate a hard budget constraint on the municipalities, mostly at the cost of the administrative subordination of the municipalities' fiscal powers to the central government. The appointment of an accountant in 30 municipalities in 2004 also highlights the lack of confidence that the central government had on the municipalities' ability (or willingness) to reach the goals of the recovery program by themselves.

\footnotetext{
11 There is a third form of local government in Israel called regional council. Regional councils are responsible for governing a number of settlements spread across rural areas. We leave regional councils out of the analysis because they have a different political system than municipalities. That said, adding them to the analysis does not change any of our conclusions. While we usually refer in the text to municipalities, we always include in the analysis municipalities and local councils.
} 
The extent of municipalities being intervened in 2004 signifies a substantial break with the policy implemented in previous years. Looking at the progression of intervention over time shows only smaller adjustments together with a lot of persistence of the different programs being used. That is, a substantial majority of municipalities intervened in 2004 continue to be intervened between 2005 and 2010. Once intervened, an average municipality remains under intervention for 4.97 years. Fifty-five municipalities are under intervention for the entire period at issue. The type of intervention chosen by the central government slightly changes over time. We observe a substantial increase on the use of summoned boards and centrally appointed accountants since 2007 mostly at the expense of recovery programs. The number of summoned boards appointed in 2007-2008 is unprecedented, and is larger than the number of appointed summoned boards in the previous five decades combined.

\subsection{Municipalities' fiscal and socio-economic data}

We study the effect of intervention on all available variables measuring the fiscal situation of municipalities, their expenditures and their ability to collect revenues. These include different measures of the localities' debt, deficit and expenditures on services, as well as their efficiency in terms of collecting local property taxes and water bills. ${ }^{12}$ The analysis also looks at the impact of the centralization program on the amount of recovery payments and equalization grants that the central government transfers to the municipalities.

Table 3 presents summary statistics for the main variables of interest. The table tabulates the municipalities according to whether or not a municipality is ever under intervention between 2004 and 2010. The table shows separate summary statistics for the two groups of municipalities for the period before the beginning of the intervention program (2000 to 2003) and the period after the beginning of the intervention program (2004 to 2010).

The table shows some of the preexistent differences between municipalities that were later on under intervention and municipalities that were never intervened. As expected, municipalities that are later on under intervention have substantially higher deficits and short-term debt than municipalities not intervened. The main objective of the intervention program was to eliminate these differences. Therefore, we label these two variables together with total economic expenditures the "final goals" of the program.

The intervention plan designed by the Interior Ministry attempted to achieve its final goals by affecting municipalities' expenditures, tax collection, recovery payments and equalization grants. Panel B in the table shows that before the intervention program, municipalities that were never intervened collected a higher share of their available property taxes and received less money from the central government. Panel $\mathrm{C}$ of the table presents the available control variables. This panel shows that municipalities under intervention between 2004-2010 are, before the intervention program, less populated, and have a lower socioeconomic status and a more fractionalized political environment, as shown by their lower share of the largest party in the local council, in comparison to the rest of the municipalities. ${ }^{13}$

We now switch our attention to the years 2004 to 2010, the period after the beginning of the intervention program. The table shows that municipalities under intervention still have higher deficit and short-term debt than municipalities not under intervention. We observe, however, a substantial change in municipalities' expenditures. Accordingly, municipalities under intervention have significantly lower expenditures compared to the rest of the municipalities.

To obtain a preliminary measure of the effects of intervention we include in this table the difference-in-differences of the average variables of interest. That is, we calculate the differences for each outcome of interest between the averages before and after the program of the differences between municipalities under intervention and the rest of the municipalities. These statistics appear in column (7). This column shows that (i) the deficit per capita of municipalities under intervention relative to the rest of the municipalities decreased by 29 percent after the beginning of the program; (ii) treated municipalities' short-term debt as a share of total revenue, however, increased by 22 percent; (iii) total expenditures per capita of municipalities under intervention (relative to the rest of municipalities) decreases after the beginning of the program by 9.9 percent, mostly due to decreases in salary payments; and (iv) there is a substantial increase in transfers from the central government to localities under intervention mostly in the form of recovery payments. All these effects are statistically different from zero at the $1 \%$ level.

\section{Empirical framework}

There are several caveats regarding the preliminary conclusions based on Table 3. First of all, they only show unconditional changes on the outcomes of interest. Below, we use a multivariate regression approach to address this issue. Secondly, Table 3 makes evident that treated and untreated municipalities are substantially different in terms of their observables before the treatment (except for total salary payments, the rest of the variables are statistically significant at least at the $5 \%$ level). Therefore, it seems safe to assume that there are significant differences between treated and untreated municipalities also in terms of their unobservable characteristics. This raises an inference problem since central intervention is correlated with the municipalities' characteristics. We address this issue below by concentrating exclusively on a more homogenous group of municipalities. In particular, we also perform all of our estimations restricting the sample of municipalities to those whose short-term debt as a share of their total revenue was in 2003 between $10 \%$ and $25 \%$. That is, given that municipalities with short-term debt as a share of total revenue above $17.5 \%$ are included in the recovery program, our discontinuity sample concentrates on municipalities within 7.5 percentage points of this threshold, and compares those treated to those that were not treated. There are 52 localities in the

\footnotetext{
12 We also include water bills collection as an output of interest because in Israel municipalities are responsible for the provision of water to their residents.

13 Related studies have shown that, especially among Arab localities, the level of political fragmentation has a significant effect on municipalities' debt (Reingewertz, 2010) and on the political participation of their residents (Ben-Bassat and Dahan, 2012).
} 

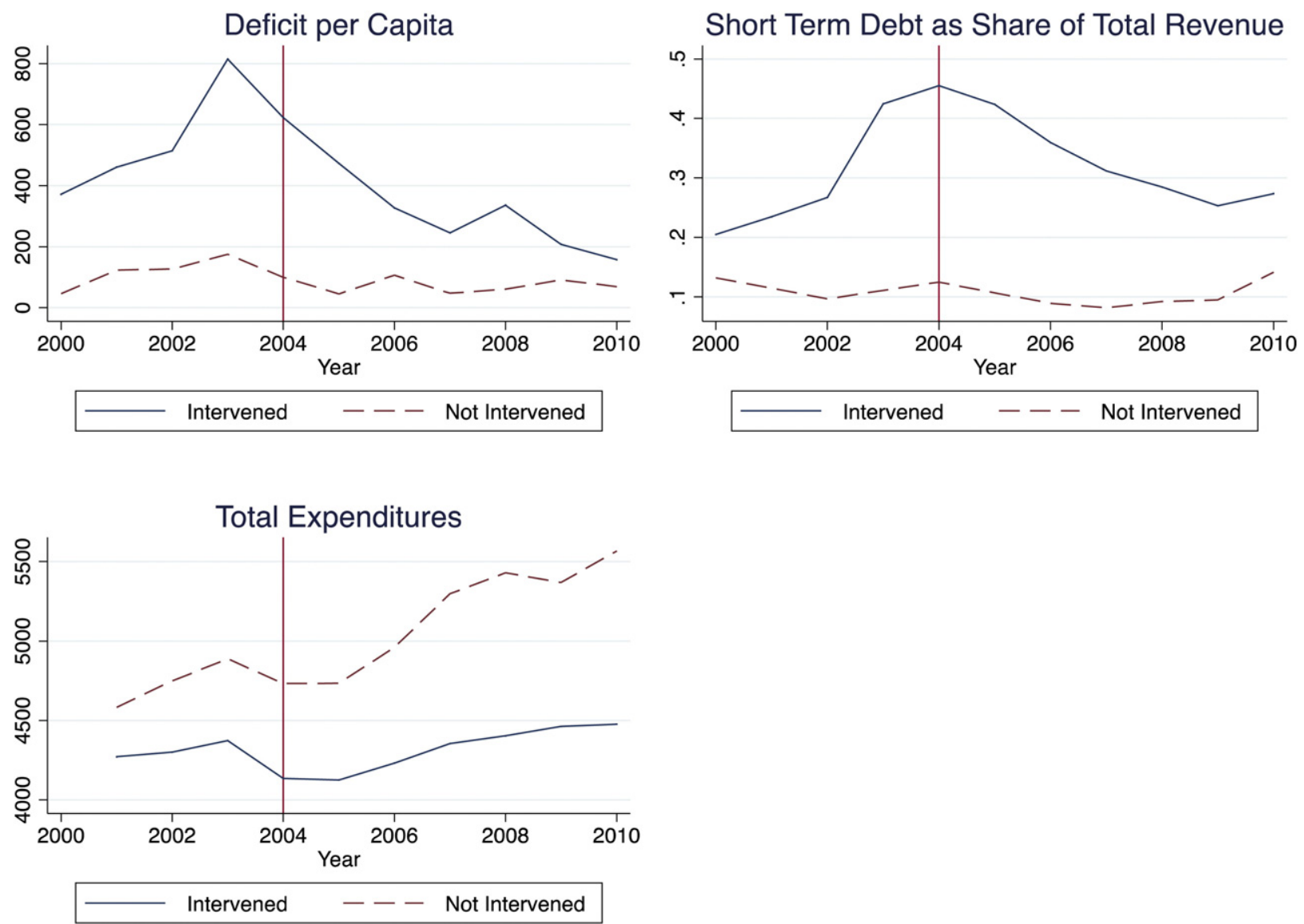

Fig. 1. Final Goals of the Intervention Program.Note: The figures depict, for every outcome of interest, the mean of the respective variable for municipalities intervened in 2004-2010 and the remainder municipalities for every year in the time period at issue.

range at issue, 27 of them were intervened in 2004 and the remainder 25 localities were not. As would be evident below, using alternative bandwidths (instead of 7.5 percentage points) delivers similar results.

A final concern is that comparing municipalities' performance before and after the implementation of the intervention program may mask differing pre-existing trends and substantial changes that occur gradually over time. Figs. 1 and 2 address this possibility. The figures depict, for every outcome of interest, the mean of the different variables for municipalities intervened in 2004-2010 and for the remainder municipalities for every year in the time period at issue. Fig. 1 focuses on the program's final goals. The figure depicts the gradual worsening fiscal situation of the treated municipalities during the years 2000-2003, before the beginning of the program. The figure also shows the gradual but slow relative improvement of the fiscal situation of treated municipalities after the program started. Importantly, however, note that after the beginning of the program, treated municipalities still have higher debt and deficit and lower expenditures than the rest of the municipalities.

Fig. 2 repeats the analysis of Fig. 1 but concentrating on the fiscal tools available to improve the municipalities' fiscal situation. Overall, Fig. 2 depicts a similar pattern to that of Fig. 1. That is, a worsening of treated municipalities' situation until 2003, mainly due to a substantial decrease in recovery payments, and a sharp turn of the slope beginning in 2004 accompanied by a gradual increase of tax revenues and transfers of treated municipalities vis-à-vis untreated municipalities.

While the figures present suggestive evidence that trends before intervention are parallel across the different outcomes, we directly test for this in Table 4 . Table 4 presents the estimation of the following model,

$$
Y_{i, t}=\mu_{i}+\delta_{t}+\sum_{j=-4}^{6} \delta_{t-j} \times(\text { EverIntervened })_{i}+u_{i, t}
$$

where $Y_{i t}$ is the outcome variable of interest, a list of which appears in Table $3 ; \delta_{t}$ is a fixed effect for each year in the sample; $\mu_{i}$ is a municipality fixed effect; (Ever Intervened) ${ }_{i}$ is a dummy variable equal to one for municipalities ever under intervention between 2004 and 2010 and zero otherwise Table 4. 

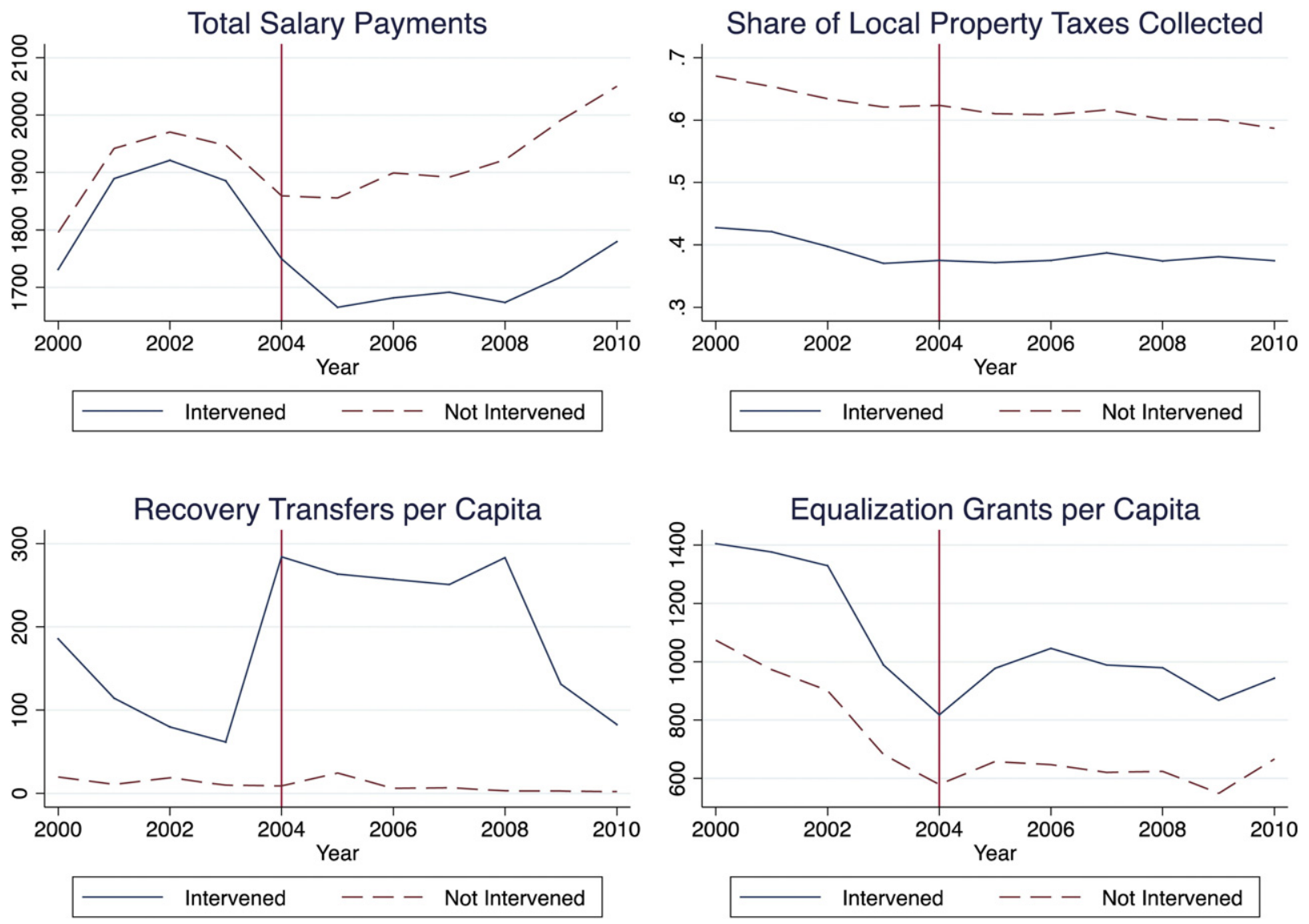

Fig. 2. Fiscal Instruments. Note: The figures depict, for every outcome of interest, the mean of the respective variable for municipalities intervened in 2004-2010 and the remainder municipalities for every year in the time period at issue.

The results in Table 4 show that the assumption of equal trends hold for municipalities total expenditures per capita, total salary payments per capita, local property taxes collected per capita, and equalization grants per capita. ${ }^{14}$ We observe differing trends for only three variables. Yet, out of those variables, for two of them the results show that intervention is associated with a reversal of the pre-existing trend. Whereas the effect of leads for municipalities' deficit per capita is positive (the coefficients' sum is 411.65), the effect for lags is negative (the coefficients' sum equals -399.68). That is, the deficit per capita of municipalities that were later on intervened was increasing vis-à-vis the rest of the municipalities before the intervention program, and decreased after the program. Hence, the effect of the program is not due to different pre-existing trends for treated and untreated municipalities. Similarly, intervened municipalities received before the intervention program less recovery payments vis-àvis the rest of the municipalities, and more payments after the program started.

Given the patterns observed in Figs. 1 and 2 and Table 4, we implement an empirical framework that pays particular attention to the gradual effect of the intervention program on the outcomes of interest. The adopted specification allows us to examine how central intervention affects the performance of municipalities taking into account that the effects of intervention may persist even after intervention ends, as suggested by the results in Table 4. Our preferred specification is given by:

$$
Y_{i, t}=\alpha(\text { Intervention })_{i, t-1}+\beta(\text { Years of Intervention })_{i, t-1}+\mathbf{X}_{i, t-1} \Phi+\delta_{t}+\mu_{i}+u_{i, t}
$$

where $Y_{i t}$ is the outcome variable of interest, a list of which appears in Table 3; (Intervention) i,t- $1_{1}$ is a dummy variable that equals one if municipality $i$ is under central intervention in year $t-1$ and zero otherwise. We use the lag of this variable because, as shown in Table 4 and Figs. 1 and 2, the effects of intervention are not realized immediately. In addition, our empirical framework also estimates the effects of the number of years under intervention. This effect is captured by the variable (Years of Intervention) ${ }_{1}{ }^{15}$ This specification allows for the effects of intervention to persist beyond the intervention period, which is in line with the

\footnotetext{
${ }^{14}$ Note that the regression for expenditures per capita omits one of the year interactions with interventions because of collinearity. This occurs only for this variable because it is the variable with the highest number of missing values.

15 The actual construction of this variable is as follows. Suppose municipality $i$ is under intervention between 2004 and 2006 and in 2008 and 2009 . For this municipality, (Years of Intervention) $)_{i, t-1}$ equals zero until 2005, equals 1 in 2005, 2 in 2006, 2007 and 2008, 3 in 2009 and 4 in 2010. The persistence of intervention over time makes this variable highly correlated with years at the municipality level. This precludes us from including municipality specific linear time trends in model (2).
} 
Table 4

Testing for Equality of trends before Intervention-Entire Sample.

\begin{tabular}{|c|c|c|c|c|c|c|c|}
\hline & $\begin{array}{l}\text { Log } \\
\text { Deficit per } \\
\text { Capita }\end{array}$ & $\begin{array}{l}\text { Short Term Debt as } \\
\text { Share of Total } \\
\text { Revenue }\end{array}$ & $\begin{array}{l}\text { Log Total } \\
\text { Expenditures } \\
\text { per Capita }\end{array}$ & $\begin{array}{l}\text { Log Total Salary } \\
\text { Payments per } \\
\text { Capita }\end{array}$ & $\begin{array}{l}\text { Log Local Property } \\
\text { Taxes Collected per } \\
\text { Capita }\end{array}$ & $\begin{array}{l}\text { Log Recovery } \\
\text { Payments per } \\
\text { Capita }\end{array}$ & $\begin{array}{l}\text { Log } \\
\text { Equalization } \\
\text { Grants per } \\
\text { Capita }\end{array}$ \\
\hline Intervention $\times 2001$ & $\begin{array}{l}22.10 \\
(52.10)\end{array}$ & $\begin{array}{l}0.0462^{* * *} \\
(0.0174)\end{array}$ & $\begin{array}{l}147.8 \\
(96.63)\end{array}$ & $\begin{array}{l}13.01 \\
(18.72)\end{array}$ & $\begin{array}{l}0.0110 \\
(0.00925)\end{array}$ & $\begin{array}{l}-59.49^{* *} \\
(27.56)\end{array}$ & $\begin{array}{l}71.89 \\
(44.84)\end{array}$ \\
\hline Intervention $\times 2002$ & $\begin{array}{l}67.25 \\
(56.81)\end{array}$ & $\begin{array}{l}0.0972^{* * * *} \\
(0.0280)\end{array}$ & & $\begin{array}{l}12.27 \\
(28.69)\end{array}$ & $\begin{array}{l}0.00707 \\
(0.0111)\end{array}$ & $\begin{array}{l}-101.4^{* * * *} \\
(34.45)\end{array}$ & $\begin{array}{l}92.74^{*} \\
(53.12)\end{array}$ \\
\hline Intervention $\times 2003$ & $\begin{array}{l}322.3^{* * * *} \\
(67.66)\end{array}$ & $\begin{array}{l}0.240^{* * * *} \\
(0.0339)\end{array}$ & $\begin{array}{l}-59.17 \\
(109.4)\end{array}$ & $\begin{array}{l}2.722 \\
(30.29)\end{array}$ & $\begin{array}{l}-0.00657 \\
(0.0124)\end{array}$ & $\begin{array}{l}-111.0^{* * * *} \\
(28.08)\end{array}$ & $\begin{array}{l}-25.29 \\
(65.56)\end{array}$ \\
\hline Intervention $\times 2004$ & $\begin{array}{l}203.7^{* * * *} \\
(64.10)\end{array}$ & $\begin{array}{l}0.257^{* * * *} \\
(0.0358)\end{array}$ & $\begin{array}{l}-144.1 \\
(116.0)\end{array}$ & $\begin{array}{l}-46.27 \\
(40.06)\end{array}$ & $\begin{array}{l}-0.00478 \\
(0.0138)\end{array}$ & $\begin{array}{l}114.2^{* * *} \\
(33.04)\end{array}$ & $\begin{array}{l}-93.42 \\
(81.74)\end{array}$ \\
\hline Intervention $\times 2005$ & $\begin{array}{l}107.3^{*} \\
(60.94)\end{array}$ & $\begin{array}{l}0.244^{* * * *} \\
(0.0416)\end{array}$ & $\begin{array}{l}-155.4 \\
(109.5)\end{array}$ & $\begin{array}{l}-127.5^{* * *} \\
(47.19)\end{array}$ & $\begin{array}{l}0.00535 \\
(0.0144)\end{array}$ & $\begin{array}{l}77.82^{*} \\
(41.10)\end{array}$ & $\begin{array}{l}-12.95 \\
(88.24)\end{array}$ \\
\hline Intervention $\times 2006$ & $\begin{array}{l}-101.3 \\
(81.88)\end{array}$ & $\begin{array}{l}0.197^{* * *} \\
(0.0402)\end{array}$ & $\begin{array}{l}-275.1^{* *} \\
(122.3)\end{array}$ & $\begin{array}{l}-155.3^{* * * *} \\
(53.50)\end{array}$ & $\begin{array}{l}0.0105 \\
(0.0143)\end{array}$ & $\begin{array}{l}89.72^{* *} \\
(39.42)\end{array}$ & $\begin{array}{l}67.07 \\
(84.58)\end{array}$ \\
\hline Intervention $\times 2007$ & $\begin{array}{l}-123.6^{* *} \\
(58.64)\end{array}$ & $\begin{array}{l}0.157^{* * * *} \\
(0.0410)\end{array}$ & $\begin{array}{l}-498.4^{* *} \\
(198.8)\end{array}$ & $\begin{array}{l}-138.1^{* * *} \\
(52.73)\end{array}$ & $\begin{array}{l}0.0156 \\
(0.0153)\end{array}$ & $\begin{array}{l}82.85^{* *} \\
(39.73)\end{array}$ & $\begin{array}{l}36.47 \\
(88.51)\end{array}$ \\
\hline Intervention $\times 2008$ & $\begin{array}{l}-45.78 \\
(85.02)\end{array}$ & $\begin{array}{l}0.119^{* * *} \\
(0.0412)\end{array}$ & $\begin{array}{l}-582.5^{* * * *} \\
(173.1)\end{array}$ & $\begin{array}{l}-187.2^{\text {**** }} \\
(55.76)\end{array}$ & $\begin{array}{l}0.0166 \\
(0.0166)\end{array}$ & $\begin{array}{l}119.0^{* * *} \\
(49.08)\end{array}$ & $\begin{array}{l}22.39 \\
(94.84)\end{array}$ \\
\hline Intervention $\times 2009$ & $\begin{array}{l}-205.7^{* * *} \\
(67.97)\end{array}$ & $\begin{array}{l}0.0846^{*} \\
(0.0432)\end{array}$ & $\begin{array}{l}-461.8^{* * *} \\
(153.5)\end{array}$ & $\begin{array}{l}-208.1^{* * *} \\
(62.34)\end{array}$ & $\begin{array}{l}0.0249 \\
(0.0166)\end{array}$ & $\begin{array}{l}-33.73 \\
(38.18)\end{array}$ & $\begin{array}{l}-11.99 \\
(111.5)\end{array}$ \\
\hline Intervention $\times 2010$ & $\begin{array}{l}-234.3^{* * *} \\
(63.00)\end{array}$ & $\begin{array}{l}0.0586 \\
(0.0716)\end{array}$ & $\begin{array}{l}-645.9^{* * *} \\
(150.2)\end{array}$ & $\begin{array}{l}-205.3^{* * *} \\
(74.54)\end{array}$ & $\begin{array}{l}0.0325 \\
(0.0232)\end{array}$ & $\begin{array}{l}-82.17^{\text {**** }} \\
(30.95)\end{array}$ & $\begin{array}{l}-53.38 \\
(126.1)\end{array}$ \\
\hline $\begin{array}{l}\text { P-value of Total Effect of } \\
\text { Intervention on leads } \\
(2001-2003)\end{array}$ & 0.0054 & 0.0000 & 0.6103 & 0.6802 & 0.6887 & 0.0015 & 0.3508 \\
\hline $\begin{array}{l}\text { P-value of Total Effect of } \\
\text { Intervention on lags } \\
(2004-2010)\end{array}$ & 0.2066 & 0.0000 & 0.0013 & 0.0024 & 0.2770 & 0.0903 & 0.9412 \\
\hline Number of observations & 2072 & 1862 & 1816 & 2083 & 2079 & 2112 & 1894 \\
\hline
\end{tabular}

Each column presents the results of a separate panel regression model. All regressions control for years and municipalities fixed effects.

* indicates statistically significant at $10 \%$ level.

** indicates statistically significant at $5 \%$ level.

**** indicates statistically significant at $1 \%$ level.

evidence presented in Table 4 showing that most of the effects of intervention are realized after 2007, even though several of intervened municipalities are not longer under intervention during those particular years. ${ }^{16} \mathbf{X}_{i t-1}$ is a vector of time-varying municipality characteristics (listed in Table 3$) ;{ }^{17} \delta_{t}$ is a fixed effect for each year in the sample to control for aggregate trends in the economic and political situation of Israel; $\mu_{i}$ is a municipality fixed effect; and $\alpha, \beta$ and the vector $\Phi$ are unknown parameters that need to be estimated. Unobserved determinants of the municipalities' performances are captured by the error term, $u_{i t}{ }^{18}$

The goal of the proposed econometric specification on model (2) is to identify the joint impact of $\alpha$ and $\beta$. We are interested on the immediate effect of intervention as well as on the protracted effect of intervention over time. Based on model (2), the immediate effect of intervention is equal to $(\alpha+\beta)$, whereas the gradual effect of intervention over time equals $\beta$.

To address the identification concerns mentioned above, we estimate model (2) for all the municipalities, and subsequently only for a selected sample of municipalities in the neighborhood of the cutoff of intervention, which have similar pretreatment characteristics. The sections below discuss all the estimations in detail.

\footnotetext{
16 This is the main reason we choose specification (2) above. Estimating an alternative standard difference-in-differences specification delivers very similar results (available from the author upon request).

17 Note that regression (2) instruments the covariates with their lagged values to eliminate possible endogeneity in panel regressions.

18 We cluster the standard errors at the municipality level. Therefore, they are robust to any type of serial correlation within clusters and heteroscedasticity of unknown type (Bertrand et al., 2004). In principle, it could be possible for standard errors to be correlated also at higher levels of government. Israel, however, is not divided into provinces or states and therefore does not have a higher level of local government over municipalities. That is, the only local level is the municipality and the only higher level over municipalities is the national government.
} 
Table 5

The Effect of Central Intervention on Municipalities' Fiscal Goals-Entire Sample.

\begin{tabular}{|c|c|c|c|}
\hline & $\begin{array}{l}\text { Log Deficit per } \\
\text { Capita }\end{array}$ & Short Term Debt as Share of Total Revenue & Log Total Expenditures per Capita \\
\hline - Intervention & $\begin{array}{l}0.4083 \\
{[0.360]}\end{array}$ & $\begin{array}{l}0.0362 \\
{[0.046]}\end{array}$ & $\begin{array}{l}-0.0097 \\
{[0.013]}\end{array}$ \\
\hline - Years of Intervention & $\begin{array}{l}-0.240^{* *} \\
{[0.11]}\end{array}$ & $\begin{array}{l}-0.0195 \\
{[0.014]}\end{array}$ & $\begin{array}{l}-0.0198^{* * *} \\
{[0.004]}\end{array}$ \\
\hline - Population Size (natural log) & $\begin{array}{l}-0.3364 \\
{[0.715]}\end{array}$ & $\begin{array}{l}0.0071 \\
{[0.070]}\end{array}$ & $\begin{array}{l}-0.2860^{* *} \\
{[0.135]}\end{array}$ \\
\hline - Socio-Economic Status & $\begin{array}{l}-0.050 \\
{[0.22]}\end{array}$ & $\begin{array}{l}0.0074 \\
{[0.017]}\end{array}$ & $\begin{array}{l}-0.0118 \\
{[0.011]}\end{array}$ \\
\hline -Log Average Salary (from previous year) & $\begin{array}{l}-0.024 \\
{[1.63]}\end{array}$ & $\begin{array}{l}-0.0551 \\
{[0.168]}\end{array}$ & $\begin{array}{l}0.0964 \\
{[0.085]}\end{array}$ \\
\hline -Share of Largest Party in Municipal Council & $\begin{array}{l}-1.0044 \\
{[0.822]}\end{array}$ & $\begin{array}{l}0.0436 \\
{[0.056]}\end{array}$ & $\begin{array}{l}-0.0250 \\
{[0.036]}\end{array}$ \\
\hline $\begin{array}{l}\text { P-value of Total Effect of Intervention } \\
\text { Number of observations }\end{array}$ & $\begin{array}{l}0.5581 \\
1185\end{array}$ & $\begin{array}{l}0.6221 \\
1449\end{array}$ & $\begin{array}{l}0.0081 \\
1569\end{array}$ \\
\hline
\end{tabular}

Each column presents the results of a separate panel regression model. All regressions include years and municipalities fixed effects. * indicates statistically significant at $10 \%$ level.

indicates statistically significant at $5 \%$ level.

**** indicates statistically significant at $1 \%$ level.

\section{Results}

Table 5 shows the effect of central intervention on municipalities' main outcomes of interest based on the estimation of model (2). Before discussing the results, we need to keep in mind that they are based on the entire sample of municipalities, and that the estimation does not differentiate between different types of hierarchical subordination. Therefore, the results may be affected by possible spurious correlations caused by ignoring the fact that treated municipalities are not randomly selected.

With this caveat in mind, the results seem to suggest that central intervention is an effective tool to lower municipalities' deficit and expenditures (consistent with the results in Table 4). We observe that the intervention of a municipality has a statistically significant protracted effect on their deficit. The coefficient shows that every year of intervention is associated with a 24 percent decrease in a municipality's deficit. The results also highlight that the effects on expenditures are statistically significant both immediately and protracted over time. According to the estimated coefficients, the administrative subordination of municipalities brings about an immediate decrease of 2.9 percent in their expenditures per capita. Moreover, every additional year under intervention is associated with a reduction of 1.98 percent in expenditures. However, Table 5 also shows that the central intervention of municipalities does not have a statistically significant effect on their short-term debt. Although the immediate effect of intervention is positive, this is probably due to previous financial commitments of intervened municipalities. That said, the results suggest that every additional year of administrative subordination is associated with a decrease in municipalities' short-term debt, though these effects are not precisely estimated. ${ }^{19}$

Table 6 shows the impact of central intervention on some of the fiscal variables that the central government uses as a tool while trying to reach the fiscal goals behind the program of administrative subordination. The results of these estimations suggest that central intervention is an effective policy to affect fiscal tools in the desired direction. It seems that every year under intervention brings about a significant decrease in salary payments, an increase in local tax collection, and an increase in equalization grants received from the central government. ${ }^{20}$

While giving us a first view at the effects of central intervention, the estimates presented in Tables 5 and 6 and the top panel of A1 may be spurious for the reasons already mentioned above. The sub-sections below address the identification concerns.

\footnotetext{
19 Fig. 1 shows that the short-term debt of intervened municipalities remains stable in 2004 (the first year of the intervention program), and sharply decreases in every subsequent year except for 2010 .

20 The available data allow us to estimate model (2) for different subcategories of the outcomes presented in Table 6. These estimations appear in Appendix Table A.1. This table shows that most of the decrease in municipalities' expenditures caused by central intervention is concentrated on municipalities' expenditures in education.
} 
Table 6

The Effect of Central Intervention on Municipalities Fiscal Tools-Entire Sample.

\begin{tabular}{|c|c|c|c|c|}
\hline & $\begin{array}{l}\text { Log Total Salary Payments } \\
\text { per Capita }\end{array}$ & $\begin{array}{l}\text { Log Local Property Taxes Collected } \\
\text { per Capita }\end{array}$ & $\begin{array}{l}\text { Log Recovery Payments } \\
\text { per Capita }\end{array}$ & $\begin{array}{l}\text { Log Equalization Grants } \\
\text { per Capita }\end{array}$ \\
\hline - Intervention & $\begin{array}{l}-0.024^{*} \\
{[0.014]}\end{array}$ & $\begin{array}{l}0.0393 \\
{[0.038]}\end{array}$ & $\begin{array}{l}1.9418^{* * *} \\
{[0.260]}\end{array}$ & $\begin{array}{l}0.0895 \\
{[0.065]}\end{array}$ \\
\hline - Years of Intervention & $\begin{array}{l}-0.015^{* * *} \\
{[0.005]}\end{array}$ & $\begin{array}{l}0.0162 \\
{[0.014]}\end{array}$ & $\begin{array}{l}-0.1437^{*} \\
{[0.075]}\end{array}$ & $\begin{array}{l}0.0720^{* * * *} \\
{[0.027]}\end{array}$ \\
\hline $\begin{array}{l}\text { P-value of Total Effect of } \\
\text { Intervention }\end{array}$ & 0.0009 & 0.0574 & 0.0000 & 0.0032 \\
\hline Number of observations & 1621 & 1620 & 1646 & 1467 \\
\hline
\end{tabular}

Each column in each panel presents the results of a separate panel regression model. All regressions control for each municipality number of residents (in logs), socio-economic status, average salary for employees (from previous year in logs), percentage of seats of larger party and number of parties (divided by number of legislators), as well as years and municipalities fixed effects. ${ }^{* *}$ indicates statistically significant at $5 \%$ level

indicates statistically significant at $10 \%$ level.

*** indicates statistically significant at $1 \%$ level.

\subsection{Using a restricted sample to account for unobserved characteristics}

An important concern related to the estimation of the effect of central intervention on municipalities' performance is that treated and untreated municipalities may differ in terms of some of their time-varying unobservable characteristics. The evidence presented in Table 3, which shows that treated and untreated municipalities differ regarding their observable characteristics, magnifies this concern.

The analysis in this subsection alleviates this concern by focusing on a subsample of more homogenous municipalities. ${ }^{21}$ In particular, hereby we focus on municipalities whose short-term debt as a share of their total revenue in 2003 was within 7.5 percentage points of the threshold used to determine their inclusion into the recovery program. ${ }^{22}$ As shown in Table 7 , the municipalities in this subsample are balanced in terms of their pre-treatment observable characteristics, which leads us to believe that they are also balanced in terms of their pre-treatment time-varying unobservable characteristics. Whereas a $t$-test for equality of means of pre-treatment characteristics is statistically significant at the $5 \%$ level for all the variables listed in Table 3 , this test is statistically significant only for pre-treatment recovery payments per capita (at the $5 \%$ level) when using the sample of municipalities in the neighborhood of the cutoff of intervention. ${ }^{23}$

In addition, we test whether any observable characteristic of municipalities in 2003 is able to predict being intervened on 2004 or onwards. The results appear in Table 8. This table displays the marginal coefficients of a probit regression of municipalities' observable characteristics (measured in 2003) on being intervened in 2004 or later. The table shows that none of the municipalities' characteristics is able to predict being intervened later on. The only exception is municipalities' short-term debt as a share of total revenue. This relationship is of course expected since the intervention threshold was determined based on this variable. Hence, Tables 7 and 8 show that this subsample of municipalities is balanced and that selection is not a serious concern.

Table 9 repeats the analysis of model (2) for the subsample of municipalities. The results in this table corroborate the main message of Tables 5 and 6. Accordingly, once we compare the effects of intervention across similar municipalities, the analysis ratifies that continued administrative subordination causes a yearly reduction of total expenditures per capita in the order of 1.86 percent (mostly due to a decrease in total salary payments). Unlike the results of Tables 5 and 6 , however, administrative subordination does not seem to have an immediate effect on the goals of interest, but rather only a protracted one.

Table 9 also reveals that intervened municipalities enjoy an immediate increase in the amount of transfers from the central government in the form of recovery payments. These payments amount to an increase of almost 170 percent compared to municipalities without intervention and do not dissipate over time. Yet, despite the fact that fiscal subordination brings about an increase in transfers from the central government and a decrease in expenditures, we do not observe any significant effect on municipalities' deficit, short-term debt or long-term debt vis-à-vis the rest of the municipalities in the control group (see also Panel B in Appendix Table A.1). As already noted above and seen in Fig. 1 and Table 4, these outcomes are more persistent over time, which may be why the intervention program does not have a statistically significantly effect on them. Importantly, as already mentioned above, the statistical and quantitative significance of the results is robust to other bounds beside 7.5 percentage points from the intervention threshold (see Appendix Table A.2).

\footnotetext{
${ }^{21}$ Given the concerns over nonrandom sample selection into treatment and unobserved heterogeneity in response to treatment, it would be useful to test the robustness of our analysis using the synthetic control method for comparative case studies developed by Abadie and Gardeazabal (2003) and Abadie et al. (2010). Unfortunately we are not able to conduct that type of analysis because we only have data for 4 years before treatment.

22 We choose to present the results using the 7.5 percentage points bandwidth because it contains a large enough sample of municipalities, yet they are still very similar in their pre-treatment characteristics. Table Appendix A2 shows that the results are the same when we use bandwidths of 5 or 10 percentage points around the threshold.

${ }^{23}$ We choose to implement this specification based on a restricted sample of municipalities and not a full regression discontinuity design because the probability of entering a recovery program is not deterministic. For example, there are 13 municipalities whose short-term debt in 2003 is over $17.5 \%$ and were not included in a recovery program in 2004, while there are 6 municipalities with short-term debt below $17.5 \%$ in 2003 that entered a recovery program in 2004 . Similar caveats apply to opting in or out of recovery programs in subsequent years.
} 
Table 7

Summary Statistics on Municipalities' Outcomes of Interest-restricted sample of municipalities.

\begin{tabular}{|c|c|c|c|c|c|c|c|}
\hline & \multicolumn{2}{|l|}{$2000-2003$} & \multicolumn{2}{|l|}{$2004-2010$} & \multicolumn{2}{|c|}{ Treated Minus Control } & \multirow{2}{*}{ Diffs-in-Diffs } \\
\hline & $\begin{array}{l}\text { Intervened } \\
\text { during } \\
2004-2010 \\
(1)\end{array}$ & $\begin{array}{l}\text { Not Intervened } \\
\text { during 2004-2010 } \\
\text { (2) }\end{array}$ & $\begin{array}{l}\text { Intervened } \\
\text { during } \\
2004-2010 \\
\text { (3) }\end{array}$ & $\begin{array}{l}\text { Not Intervened } \\
\text { during 2004-2010 } \\
\text { (4) }\end{array}$ & $\begin{array}{l}2000-2003 \\
(5)\end{array}$ & $\begin{array}{l}2004-2010 \\
(6)\end{array}$ & \\
\hline \multicolumn{8}{|l|}{$\begin{array}{l}\text { Outcomes of Interest } \\
\text { A. Final Goals }\end{array}$} \\
\hline - Deficit (NIS per capita) & $\begin{array}{l}277 \\
(274)\end{array}$ & $\begin{array}{l}172 \\
(196)\end{array}$ & $\begin{array}{l}236 \\
(403)\end{array}$ & $\begin{array}{l}145 \\
(364)\end{array}$ & $\begin{array}{l}104.91 \\
{[75.06]}\end{array}$ & $\begin{array}{l}90.93 \\
{[76.77]}\end{array}$ & $\begin{array}{l}-13.98 \\
{[62.31]}\end{array}$ \\
\hline $\begin{array}{l}\text { - Short Term Debt as a } \\
\text { share of Total Revenue }\end{array}$ & $\begin{array}{l}0.126 \\
(0.069)\end{array}$ & $\begin{array}{l}0.120 \\
(0.057)\end{array}$ & $\begin{array}{l}0.178 \\
(0.117)\end{array}$ & $\begin{array}{l}0.132 \\
(0.077)\end{array}$ & $\begin{array}{l}0.006 \\
{[0.014]}\end{array}$ & $\begin{array}{l}0.046^{* *} \\
{[0.020]}\end{array}$ & $\begin{array}{l}0.040 \\
{[0.027]}\end{array}$ \\
\hline $\begin{array}{l}\text { - Total Economic } \\
\text { Expenditures (NIS per } \\
\text { capita) }\end{array}$ & $\begin{array}{l}4149 \\
(1438)\end{array}$ & $\begin{array}{l}4409 \\
(695)\end{array}$ & $\begin{array}{l}4287 \\
(1230)\end{array}$ & $\begin{array}{l}4781 \\
(1012)\end{array}$ & $\begin{array}{l}-260.30 \\
{[295.21]}\end{array}$ & $\begin{array}{l}-493.93 \\
{[318.56]}\end{array}$ & $\begin{array}{l}-233.64 \\
{[157.45]}\end{array}$ \\
\hline \multicolumn{8}{|l|}{ B. Fiscal Instruments } \\
\hline $\begin{array}{l}\text { - Total Salary Payments } \\
\text { (NIS per capita) }\end{array}$ & $\begin{array}{l}1702 \\
(461)\end{array}$ & $\begin{array}{l}1784 \\
(387)\end{array}$ & $\begin{array}{l}1593 \\
(450)\end{array}$ & $\begin{array}{l}1768 \\
(511)\end{array}$ & $\begin{array}{l}-81.89 \\
{[124.17]}\end{array}$ & $\begin{array}{l}-175.66 \\
{[153.10]}\end{array}$ & $\begin{array}{l}-93.77 \\
{[70.41]}\end{array}$ \\
\hline $\begin{array}{l}\text { - Share of Local Property } \\
\text { Taxes Collected }\end{array}$ & $\begin{array}{l}0.49 \\
(0.270)\end{array}$ & $\begin{array}{l}0.58 \\
(0.220)\end{array}$ & $\begin{array}{l}0.4 \\
(0.261)\end{array}$ & $\begin{array}{l}0.5 \\
(0.220)\end{array}$ & $\begin{array}{l}-0.093 \\
{[0.074]}\end{array}$ & $\begin{array}{l}-0.102 \\
{[0.072]}\end{array}$ & $\begin{array}{l}-0.009 \\
{[0.021]}\end{array}$ \\
\hline $\begin{array}{l}\text { - Recovery Payments per } \\
\text { Capita }\end{array}$ & $\begin{array}{l}62 \\
(114)\end{array}$ & $\begin{array}{l}22 \\
(51)\end{array}$ & $\begin{array}{l}120 \\
(246)\end{array}$ & $\begin{array}{l}19 \\
(82)\end{array}$ & $\begin{array}{l}39.98^{* *} \\
{[14.69]}\end{array}$ & $\begin{array}{l}101.39^{* * *} \\
{[29.95]}\end{array}$ & $\begin{array}{l}61.41^{* *} \\
{[26.29]}\end{array}$ \\
\hline $\begin{array}{l}\text { - Equalization Grants (NIS } \\
\text { per capita) }\end{array}$ & $\begin{array}{l}1203 \\
(912)\end{array}$ & $\begin{array}{l}798 \\
(599)\end{array}$ & $\begin{array}{l}887 \\
(636)\end{array}$ & $\begin{array}{l}525 \\
(463)\end{array}$ & $\begin{array}{l}405.27^{*} \\
{[225.43]}\end{array}$ & $\begin{array}{l}361.77^{* *} \\
{[166.93]}\end{array}$ & $\begin{array}{l}-43.50 \\
{[85.50]}\end{array}$ \\
\hline \multicolumn{8}{|l|}{$\begin{array}{l}\text { C. Control Variables of } \\
\text { Interest }\end{array}$} \\
\hline $\begin{array}{l}\text { - Population Size (in } \\
\text { thousands) }\end{array}$ & $\begin{array}{l}34.5 \\
(109)\end{array}$ & $\begin{array}{l}44.5 \\
(48)\end{array}$ & $\begin{array}{l}39.4 \\
(121)\end{array}$ & $\begin{array}{l}48.6 \\
(52)\end{array}$ & $\begin{array}{l}-9.957 \\
{[22.527]}\end{array}$ & $\begin{array}{l}-9.154 \\
{[24.729]}\end{array}$ & $\begin{array}{l}0.803 \\
{[2.569]}\end{array}$ \\
\hline - Socio-Economic Status & $\begin{array}{l}4.3 \\
(2.446)\end{array}$ & $\begin{array}{l}5.6 \\
(1.855)\end{array}$ & $\begin{array}{l}4.4 \\
(2.398)\end{array}$ & $\begin{array}{l}5.8 \\
(1.738)\end{array}$ & $\begin{array}{l}-1.305 \\
{[0.841]}\end{array}$ & $\begin{array}{l}-1.355 \\
{[0.813]}\end{array}$ & $\begin{array}{l}-0.050 \\
{[0.110]}\end{array}$ \\
\hline $\begin{array}{l}\text { - Share of Largest Party in } \\
\text { Municipal Council }\end{array}$ & $\begin{array}{l}0.310 \\
(0.150)\end{array}$ & $\begin{array}{l}0.332 \\
(0.106)\end{array}$ & $\begin{array}{l}0.302 \\
(0.131)\end{array}$ & $\begin{array}{l}0.305 \\
(0.109)\end{array}$ & $\begin{array}{l}-0.022 \\
{[0.038]}\end{array}$ & $\begin{array}{l}-0.003 \\
{[0.027]}\end{array}$ & $\begin{array}{l}0.019 \\
{[0.027]}\end{array}$ \\
\hline
\end{tabular}

Notes: Data from ICBS. The numbers on each cell are the means of the respective variable listed on the left column. Standard deviations appear in parentheses in columns (1) to (4). Standard errors appear in brackets in columns (5), (6) and (7).

* represent statistical significance at $10 \%$ levels.

*** represent statistical significance at $5 \%$ levels.

**** represent statistical significance at $1 \%$ levels.

\subsection{Differentiating by type of intervention}

The previous sub-section showed that central intervention has a significant effect on total expenditures (by reducing total salary payments), on local property tax collection, and on transfers from the central government. That analysis, however, does not distinguish between the different forms of administrative subordination implemented by the central government. This is the focus of the current subsection.

As already discussed in Section 2, the Israeli government implemented three different types of central intervention: (i) the appointment of an accountant that reports directly to the central government; (ii) the imposition of a recovery program; and (iii) dismissing the mayor and members of the local council while imposing a summoned board as the main authority of the municipality. Clearly, the level of central intrusiveness on local policies increases gradually as we move from an intervention of type (i), to one of type (ii), and to one of type (iii), which not only imposes administrative subordination, but also political subordination of the municipality to the central government. Given the stark differences across the three types of interventions, we ask ourselves: Is a more intrusive type of intervention necessary to achieve the central government's goals or rather, these goals may also be achieved with a more lenient form of intervention?

This subsection addresses this issue by differentiating between the effect of appointing an accountant and that of imposing a recovery program, the two more widely used types of interventions (see Table 2 ). ${ }^{24}$ The results of this estimation appear in

\footnotetext{
${ }^{24}$ We do not assess the effect of summoned boards on the outcomes of interest because there are only three municipalities with a summoned board in the relevant neighborhood of the cutoff. Moreover, the summoned boards of these municipalities were imposed in 2007, which gives us six observations for municipalities with a summoned board. Therefore, we do not have enough within-municipality or between-municipalities variation to ascertain whether this type of intervention has a significant effect when implemented over a number of years. That said, controlling for this type of intervention does not affect any of the results of Table 10 (see Appendix Table A.3)
} 
Table 8

Testing for Selection into Intervention Program.

\begin{tabular}{|c|c|c|c|c|c|c|c|c|}
\hline & $(1)$ & $(2)$ & (3) & $(4)$ & $(5)$ & $(6)$ & $(7)$ & $(8)$ \\
\hline Log Deficit for Capita & $\begin{array}{l}0.146 \\
(0.131)\end{array}$ & & & & & & & $\begin{array}{l}-0.287 \\
(0.218)\end{array}$ \\
\hline Short Term Debt as a Share of Total Revenue & & $\begin{array}{l}5.313^{* *} \\
(2.102)\end{array}$ & & & & & & $\begin{array}{l}7.751^{* *} \\
(3.370)\end{array}$ \\
\hline Log Total Expenditures Per Capita & & & $\begin{array}{l}-0.405 \\
(0.484)\end{array}$ & & & & & $\begin{array}{l}-0.407 \\
(0.694)\end{array}$ \\
\hline Log Total Salary Payments per Capita & & & & $\begin{array}{l}-0.0460 \\
(0.386)\end{array}$ & & & & $\begin{array}{l}-0.138 \\
(0.580)\end{array}$ \\
\hline Log Local Property Taxes Collected per Capita & & & & & $\begin{array}{l}0.0930 \\
(0.118)\end{array}$ & & & $\begin{array}{l}0.0982 \\
(0.120)\end{array}$ \\
\hline Log Recovery Payments per Capita & & & & & & $\begin{array}{l}-0.0174 \\
(0.0439)\end{array}$ & & $\begin{array}{l}0.0476 \\
(0.0482)\end{array}$ \\
\hline Log Equalization Grants per Capita & & & & & & & $\begin{array}{l}0.0825 \\
(0.117)\end{array}$ & $\begin{array}{l}0.234 \\
(0.236)\end{array}$ \\
\hline Log Population Size & $\begin{array}{l}-0.0686 \\
(0.0774)\end{array}$ & $\begin{array}{l}-0.121 \\
(0.0744)\end{array}$ & $\begin{array}{l}-0.108 \\
(0.0726)\end{array}$ & $\begin{array}{l}-0.0969 \\
(0.0727)\end{array}$ & $\begin{array}{l}-0.126 \\
(0.0810)\end{array}$ & $\begin{array}{l}-0.0993 \\
(0.0705)\end{array}$ & $\begin{array}{l}-0.0379 \\
(0.0943)\end{array}$ & $\begin{array}{l}-0.156 \\
(0.109)\end{array}$ \\
\hline Socio-Economic Status & $\begin{array}{l}-0.155 \\
(0.103)\end{array}$ & $\begin{array}{l}-0.0473 \\
(0.0918)\end{array}$ & $\begin{array}{l}-0.0382 \\
(0.106)\end{array}$ & $\begin{array}{l}-0.0807 \\
(0.0935)\end{array}$ & $\begin{array}{l}-0.136 \\
(0.114)\end{array}$ & $\begin{array}{l}-0.0824 \\
(0.0910)\end{array}$ & $\begin{array}{c}-0.0326 \\
(0.0940)\end{array}$ & $\begin{array}{l}0.0431 \\
(0.128)\end{array}$ \\
\hline Log Average Salary & $\begin{array}{l}0.838 \\
(0.921)\end{array}$ & $\begin{array}{l}0.0329 \\
(0.769)\end{array}$ & $\begin{array}{l}-0.191 \\
(0.818)\end{array}$ & $\begin{array}{l}0.0203 \\
(0.785)\end{array}$ & $\begin{array}{l}0.125 \\
(0.778)\end{array}$ & $\begin{array}{l}-0.000887 \\
(0.769)\end{array}$ & $\begin{array}{l}-0.0506 \\
(0.728)\end{array}$ & $\begin{array}{l}0.0297 \\
(0.828)\end{array}$ \\
\hline Share of Largest Party in Municipal Council & $\begin{array}{c}-0.459 \\
(0.626)\end{array}$ & $\begin{array}{l}-0.0791 \\
(0.752)\end{array}$ & $\begin{array}{c}-0.484 \\
(0.673)\end{array}$ & $\begin{array}{l}-0.407 \\
(0.676)\end{array}$ & $\begin{array}{l}-0.130 \\
(0.751)\end{array}$ & $\begin{array}{c}-0.473 \\
(0.681)\end{array}$ & $\begin{array}{l}-0.395 \\
(0.604)\end{array}$ & $\begin{array}{l}0.00503 \\
(1.118)\end{array}$ \\
\hline Number of observations & 40 & 41 & 41 & 41 & 41 & 41 & 38 & 37 \\
\hline
\end{tabular}

Notes: Each column presents the results of a separate probit regression. * indicates statistically significant at $10 \%$ level, ${ }^{* * *}$ indicates statistically significant at $1 \%$ level.

indicates statistically significant at $5 \%$ level.

Table 10. This table corroborates the conclusions obtained in Table 9. Central intervention affects mostly total expenditures, local property tax collection, and transfers received as recovery payments. On top of that, Table 10 shows that most of the reduction in expenditures and increase in tax collections are caused by the appointment of an accountant, which is the less intrusive of the

Table 9

The Effect of Central Intervention on Municipalities Final Goals and Fiscal Tools (focusing only on municipalities within 7.5 percentage points of intervention cutoff).

\begin{tabular}{|c|c|c|c|c|c|c|c|}
\hline & \multicolumn{3}{|l|}{ Fiscal Goals } & \multicolumn{4}{|l|}{ Fiscal Tools } \\
\hline & $\begin{array}{l}\text { Log Deficit } \\
\text { per Capita }\end{array}$ & $\begin{array}{l}\text { Short Term Debt as } \\
\text { Share of Total } \\
\text { Revenue }\end{array}$ & $\begin{array}{l}\text { Log Total } \\
\text { Expenditures } \\
\text { per Capita }\end{array}$ & $\begin{array}{l}\text { Log Total Salary } \\
\text { Payments per } \\
\text { Capita }\end{array}$ & $\begin{array}{l}\text { Log Local Property } \\
\text { Taxes Collected per } \\
\text { Capita }\end{array}$ & $\begin{array}{l}\text { Log Recovery } \\
\text { Payments per } \\
\text { Capita }\end{array}$ & $\begin{array}{l}\text { Log Equalization } \\
\text { Grants per } \\
\text { Capita }\end{array}$ \\
\hline - Intervention & $\begin{array}{l}-0.2457 \\
{[0.767]}\end{array}$ & $\begin{array}{l}0.0062 \\
{[0.024]}\end{array}$ & $\begin{array}{l}-0.0046 \\
{[0.026]}\end{array}$ & $\begin{array}{l}0.011 \\
{[0.027]}\end{array}$ & $\begin{array}{l}-0.0363 \\
{[0.053]}\end{array}$ & $\begin{array}{l}1.7018^{* * * *} \\
{[0.488]}\end{array}$ & $\begin{array}{l}-0.0301 \\
{[0.103]}\end{array}$ \\
\hline \multirow{2}{*}{$\begin{array}{l}\text { - Years of } \\
\text { Intervention }\end{array}$} & 0.1286 & -0.0022 & $-0.0186^{* *}$ & $-0.0278^{* *}$ & 0.0220 & 0.0508 & 0.0624 \\
\hline & {$[0.230]$} & [0.007] & {$[0.008]$} & {$[0.013]$} & {$[0.026]$} & [0.189] & {$[0.040]$} \\
\hline $\begin{array}{l}\text { P-value of Total } \\
\text { Effect of } \\
\text { Intervention }\end{array}$ & 0.8453 & 0.8372 & 0.2676 & 0.4279 & 0.7606 & 0.0000 & 0.6678 \\
\hline $\begin{array}{l}\text { Number of } \\
\text { observations }\end{array}$ & 319 & 400 & 426 & 425 & 426 & 427 & 392 \\
\hline
\end{tabular}

Each column in each panel presents the results of a separate panel regression model. All regressions control for each municipality number of residents (in logs), socio-economic status, average salary for employees (from previous year in logs), percentage of seats of larger party and number of parties (divided by number of legislators), as well as years and municipalities fixed effects. * indicates statistically significant at $10 \%$ level,

i* indicates statistically significant at $5 \%$ level.

*** indicates statistically significant at $1 \%$ level. 
Table 10

The Marginal Effect of Each Type of Intervention on Municipalities Outcomes of Interest-Including only municipalities within 7.5 percentage points of intervention threshold.

\begin{tabular}{|c|c|c|c|c|c|c|c|}
\hline & $\begin{array}{l}\text { Log Deficit } \\
\text { per Capita }\end{array}$ & $\begin{array}{l}\text { Short Term Debt as } \\
\text { Share of Total } \\
\text { Revenue }\end{array}$ & $\begin{array}{l}\text { Log Total } \\
\text { Expenditures per } \\
\text { Capita }\end{array}$ & $\begin{array}{l}\text { Log Total Salary } \\
\text { Payments per } \\
\text { Capita }\end{array}$ & $\begin{array}{l}\text { Log Local Property } \\
\text { Taxes Collected per } \\
\text { Capita }\end{array}$ & $\begin{array}{l}\text { Log Recovery } \\
\text { Payments per } \\
\text { Capita }\end{array}$ & $\begin{array}{l}\text { Log Equalization } \\
\text { Grants per Capita }\end{array}$ \\
\hline \multirow{2}{*}{$\begin{array}{l}\text { Effect of } \\
\text { Accoun- } \\
\text { tant } \\
\text { Interven- } \\
\text { tion }\end{array}$} & 0.1859 & 0.0450 & $-0.0566^{*}$ & -0.0349 & 0.0758 & 0.5210 & 0.1104 \\
\hline & {$[0.752]$} & [0.030] & {$[0.030]$} & [0.053] & [0.067] & [0.687] & {$[0.066]$} \\
\hline \multirow{2}{*}{$\begin{array}{l}\text { Effect of } \\
\text { Years of } \\
\text { Accoun- } \\
\text { tant } \\
\text { Interven- } \\
\text { tion }\end{array}$} & 0.0076 & -0.0058 & $-0.0271^{* *}$ & $-0.0446^{* *}$ & 0.0305 & 0.1809 & 0.0008 \\
\hline & {$[0.254]$} & {$[0.011]$} & {$[0.011]$} & {$[0.020]$} & {$[0.042]$} & {$[0.218]$} & {$[0.022]$} \\
\hline \multirow{2}{*}{$\begin{array}{l}\text { Effect of } \\
\text { Recovery } \\
\text { Program }\end{array}$} & -0.1317 & -0.0137 & -0.0209 & -0.0086 & -0.0207 & $2.1679^{* * *}$ & -0.0292 \\
\hline & [0.619] & {$[0.018]$} & {$[0.021]$} & {$[0.016]$} & {$[0.048]$} & [0.312] & {$[0.068]$} \\
\hline \multirow{2}{*}{$\begin{array}{l}\text { Effect of } \\
\text { Years of } \\
\text { Recovery } \\
\text { Program }\end{array}$} & 0.0574 & 0.0001 & 0.0200 & 0.0160 & -0.0137 & $-0.2923^{*}$ & $0.0856^{*}$ \\
\hline & [0.272] & [0.009] & {$[0.018]$} & [0.015] & {$[0.038]$} & [0.152] & [0.051] \\
\hline $\begin{array}{l}\text { P-Value of } \\
\text { Effect of } \\
\text { Accoun- } \\
\text { tant } \\
\text { Interven- } \\
\text { tion }\end{array}$ & 0.7325 & 0.1035 & 0.0142 & 0.1157 & 0.0183 & 0.2381 & 0.0804 \\
\hline $\begin{array}{l}\text { P-Value of } \\
\text { Effect of } \\
\text { Recovery } \\
\text { Program }\end{array}$ & 0.8751 & 0.3889 & 0.9507 & 0.6315 & 0.3839 & 0.0000 & 0.2878 \\
\hline $\begin{array}{l}\text { Number of } \\
\text { observa- } \\
\text { tions }\end{array}$ & 319 & 400 & 426 & 425 & 426 & 427 & 392 \\
\hline
\end{tabular}

Each column presents the results of a separate panel regression model. All regressions control for each municipality number of residents (in logs), socio-economic status, average salary for employees (from previous year in logs), percentage of seats of larger party and number of parties (divided by number of legislators), as well as years and municipalities fixed effects. P-Value of $F$-Test of joint effect of interest appears in parentheses below the respective coefficient.

" indicates statistically significant at $10 \%$ level.

** indicates statistically significant at $5 \%$ level.

**** indicates statistically significant at $1 \%$ level.

three types of interventions. ${ }^{25}$ Interestingly, the imposition of a recovery program does not seem to have a significant effect on any of the fiscal outcomes of interest even though it is accompanied by a substantial increase in recovery payments from the central government. ${ }^{26}$

This analysis alleviates some of the concerns that selection into the program is an important factor behind our results. Whereas some municipalities slightly below the threshold could select themselves into a recovery program, the imposition of a centrally appointed accountant or a summoned board was completely under the jurisdiction of the Interior Ministry. The latter two forms of intervention were based on clear and predetermined rules, and without allowing municipalities to select themselves in or out of these programs.

\footnotetext{
${ }^{25}$ According to the estimated coefficients, recovery programs seem to have a negative effect on property tax collection. This is the reason that the intervention program as a whole does not have a statistically significant impact on property tax collection (see results in Tables 3 and 4 using the entire sample and Tables 7 and 9 for the restricted sample).

${ }^{26}$ In a related theoretical analysis, Blanchard and Shleifer (2001) claim that the central appointment of a public official leads to the improvement of a locality's performance compared to the case when officials are elected in local elections. See also Enikolopov and Zhuravskaya (2007) who, based on a cross-countries analysis and without being able to differentiate between different types of intervention, found that administrative subordination is not effective.
} 


\section{Conclusions}

This paper studies the effects of hierarchical subordination on municipalities' fiscal performance. Our main results show that administrative subordination is an effective tool to bring about a decrease in municipalities' expenditures and an increase in local tax collection, without affecting the municipalities' provision of public goods. In addition, we show that different types of administrative subordination do not equally promote the desired changes on municipalities' fiscal behavior. The imposition of a recovery program, which is especially tailored for each municipality and is supposed to incentivize local politicians into adopting sound fiscal policies, does not have a significant effect on municipalities' performances. On the contrary, a less intrusive (and simpler to implement) program that consist of the appointment of an accountant that reports directly to the central government causes a significant improvement in the fiscal performances of localities under intervention. We therefore conclude that an effective policy to cope with problems related to the existence of soft-budget constraints is the imposition of a relatively mild and straightforward form of administrative subordination based on clear and predetermined rules.

\section{Acknowledgments}

We are grateful to Eric Gould, Udi Nisan, Yaniv Reingewertz, two anonymous reviewers and Thomas Stratmann (editor of EJPE) for very helpful discussions and suggestions. We have also benefited from comments from seminar participants at the School of Public Policy at the Hebrew University, the Bank of Israel, and the Israeli Democracy Institute, as well as participants at the IV Workshop on Fiscal Federalism at IEB and at the 67th Congress of the International Institute of Public Finance. We thank Lili Faintoch from the Israeli Interior Ministry for helping us collect the data on central interventions on municipalities. We especially thank our research assistants, Kfir Batz, Eli Berglass and Rotem Horowitz for their excellent work on collecting and organizing the data.

Table A.1

The effect of central intervention on other outcomes of interest.

\begin{tabular}{|c|c|c|c|c|c|c|c|}
\hline & $\begin{array}{l}\text { Debt as Share } \\
\text { of Total } \\
\text { Revenue }\end{array}$ & $\begin{array}{l}\text { Log Debt } \\
\text { per } \\
\text { Capita }\end{array}$ & $\begin{array}{l}\text { Log Expenditures on } \\
\text { Education (per } \\
\text { Capita) }\end{array}$ & $\begin{array}{l}\text { Log Expenditures } \\
\text { on Welfare (per } \\
\text { Capita) }\end{array}$ & $\begin{array}{l}\text { Log Salary Payments } \\
\text { For Education (per } \\
\text { Capita) }\end{array}$ & $\begin{array}{l}\text { Log Salary Payments } \\
\text { for Welfare (per } \\
\text { Capita) }\end{array}$ & $\begin{array}{l}\text { Log Local } \\
\text { Water Taxes } \\
\text { Collected }\end{array}$ \\
\hline & \multicolumn{7}{|l|}{ Entire Sample } \\
\hline - Intervention & $\begin{array}{l}0.035 \\
{[0.055]}\end{array}$ & $\begin{array}{l}0.0812 \\
{[0.064]}\end{array}$ & $\begin{array}{l}-0.0063 \\
{[0.019]}\end{array}$ & $\begin{array}{l}-0.0391^{* *} \\
{[0.018]}\end{array}$ & $\begin{array}{l}-0.023 \\
{[0.026]}\end{array}$ & $\begin{array}{l}-0.0273 \\
{[0.027]}\end{array}$ & $\begin{array}{l}-0.0106 \\
{[0.092]}\end{array}$ \\
\hline $\begin{array}{l}\text { - Years of } \\
\text { Intervention }\end{array}$ & $\begin{array}{l}-0.028 \\
{[0.019]}\end{array}$ & $\begin{array}{l}-0.0398^{*} \\
{[0.020]}\end{array}$ & $\begin{array}{l}-0.0211^{\text {*** }} \\
{[0.006]}\end{array}$ & $\begin{array}{l}0.0071 \\
{[0.007]}\end{array}$ & $\begin{array}{l}-0.016^{*} \\
{[0.008]}\end{array}$ & $\begin{array}{l}0.0014 \\
{[0.010]}\end{array}$ & $\begin{array}{l}0.0727^{*} \\
{[0.039]}\end{array}$ \\
\hline $\begin{array}{l}\text { P-value of Total } \\
\text { Effect of } \\
\text { Intervention }\end{array}$ & 0.8586 & 0.4220 & 0.0826 & 0.0363 & 0.0869 & 0.1999 & 0.3700 \\
\hline \multirow[t]{2}{*}{$\begin{array}{l}\text { Number of } \\
\text { observations }\end{array}$} & 1437 & 1443 & 1623 & 1623 & 1623 & 1616 & 1473 \\
\hline & \multicolumn{7}{|c|}{ Only Municipalities within 7.5 percentage points of Intervention Cutoff } \\
\hline - Intervention & $\begin{array}{l}-0.014 \\
{[0.046]}\end{array}$ & $\begin{array}{l}-0.0333 \\
{[0.070]}\end{array}$ & $\begin{array}{l}0.0384 \\
{[0.031]}\end{array}$ & $\begin{array}{l}-0.0333 \\
{[0.036]}\end{array}$ & $\begin{array}{l}0.0693 \\
{[0.052]}\end{array}$ & $\begin{array}{l}-0.0749 \\
{[0.066]}\end{array}$ & $\begin{array}{l}-0.0436 \\
{[0.188]}\end{array}$ \\
\hline $\begin{array}{l}\text { - Years of } \\
\text { Intervention }\end{array}$ & $\begin{array}{l}0.001 \\
{[0.018]}\end{array}$ & $\begin{array}{l}0.0158 \\
{[0.031]}\end{array}$ & $\begin{array}{l}-0.0244 \\
{[0.017]}\end{array}$ & $\begin{array}{l}0.0057 \\
{[0.015]}\end{array}$ & $\begin{array}{l}-0.0320 \\
{[0.022]}\end{array}$ & $\begin{array}{l}0.0231 \\
{[0.025]}\end{array}$ & $\begin{array}{l}0.1452 \\
{[0.089]}\end{array}$ \\
\hline $\begin{array}{l}\text { P-value of Total } \\
\text { Effect of } \\
\text { Intervention }\end{array}$ & 0.7216 & 0.7618 & 0.5189 & 0.2833 & 0.3654 & 0.2323 & 0.4436 \\
\hline $\begin{array}{l}\text { Number of } \\
\text { observations }\end{array}$ & 396 & 398 & 426 & 426 & 426 & 426 & 383 \\
\hline
\end{tabular}

Each column in each panel presents the results of a separate panel regression model. All regressions control for each municipality number of residents (in logs), socio-economic status, average salary for employees (from previous year in logs), percentage of seats of larger party and number of parties (divided by number of legislators), as well as years and municipalities fixed effects.

indicates statistically significant at $10 \%$ level,

** indicates statistically significant at 5\% level;

indicates statistically significant at $1 \%$ level. 
Table A2

The effect of central intervention on municipalities final goals and fiscal tools.

\begin{tabular}{|c|c|c|c|c|c|c|c|}
\hline & \multicolumn{7}{|c|}{ Focusing only on municipalities within 5 percentage points of intervention cutoff } \\
\hline & \multicolumn{3}{|l|}{ Fiscal Goals } & \multicolumn{4}{|l|}{ Fiscal Tools } \\
\hline & $\begin{array}{l}\text { Log } \\
\text { Deficit per } \\
\text { Capita }\end{array}$ & $\begin{array}{l}\text { Short Term Debt as } \\
\text { Share of Total } \\
\text { Revenue }\end{array}$ & $\begin{array}{l}\text { Log Total } \\
\text { Expenditures per } \\
\text { Capita }\end{array}$ & $\begin{array}{l}\text { Log Total Salary } \\
\text { Payments per } \\
\text { Capita }\end{array}$ & $\begin{array}{l}\text { Log Local Property } \\
\text { Taxes Collected per } \\
\text { Capita }\end{array}$ & $\begin{array}{l}\text { Log Recovery } \\
\text { Payments per } \\
\text { Capita }\end{array}$ & $\begin{array}{l}\text { Log Equalization } \\
\text { Grants per } \\
\text { Capita }\end{array}$ \\
\hline - Intervention & $\begin{array}{l}-0.2070 \\
{[1.048]}\end{array}$ & $\begin{array}{l}0.0070 \\
{[0.027]}\end{array}$ & $\begin{array}{l}0.0152 \\
{[0.025]}\end{array}$ & $\begin{array}{l}0.0275 \\
{[0.030]}\end{array}$ & $\begin{array}{l}-0.0769 \\
{[0.060]}\end{array}$ & $\begin{array}{l}1.5599^{* * *} \\
{[0.496]}\end{array}$ & $\begin{array}{l}0.0243 \\
{[0.096]}\end{array}$ \\
\hline $\begin{array}{l}\text { - Years of } \\
\text { Intervention }\end{array}$ & $\begin{array}{l}-0.0121 \\
{[0.334]}\end{array}$ & $\begin{array}{l}-0.0048 \\
{[0.010]}\end{array}$ & $\begin{array}{l}-0.0251^{\text {*** }} \\
{[0.0078]}\end{array}$ & $\begin{array}{l}-0.0376^{* *} \\
{[0.016]}\end{array}$ & $\begin{array}{l}0.0375 \\
{[0.031]}\end{array}$ & $\begin{array}{l}0.0902 \\
{[0.1592]}\end{array}$ & $\begin{array}{l}0.0350 \\
{[0.040]}\end{array}$ \\
\hline $\begin{array}{l}\text { P-value of Total } \\
\text { Effect of } \\
\text { Intervention }\end{array}$ & 0.7756 & 0.9182 & 0.6142 & 0.6730 & 0.4905 & 0.0003 & 0.4166 \\
\hline \multirow{4}{*}{$\begin{array}{l}\text { Number of } \\
\text { observations }\end{array}$} & 221 & 290 & 313 & 312 & 313 & 314 & 295 \\
\hline & \multicolumn{7}{|c|}{ Focusing only on municipalities within 10 percentage points of intervention cutoff } \\
\hline & \multicolumn{3}{|l|}{ Fiscal Goals } & \multicolumn{4}{|l|}{ Fiscal Tools } \\
\hline & $\begin{array}{l}\text { Log } \\
\text { Deficit per } \\
\text { Capita }\end{array}$ & $\begin{array}{l}\text { Short Term Debt as } \\
\text { Share of Total } \\
\text { Revenue }\end{array}$ & $\begin{array}{l}\text { Log Total } \\
\text { Expenditures } \\
\text { per Capita }\end{array}$ & $\begin{array}{l}\text { Log Total Salary } \\
\text { Payments per Capita }\end{array}$ & $\begin{array}{l}\text { Log Local Property } \\
\text { Taxes Collected per } \\
\text { Capita }\end{array}$ & $\begin{array}{l}\text { Log Recovery } \\
\text { Payments per } \\
\text { Capita }\end{array}$ & $\begin{array}{l}\text { Log Equalization } \\
\text { Grants per } \\
\text { Capita }\end{array}$ \\
\hline - Intervention & $\begin{array}{l}0.2097 \\
{[0.609]}\end{array}$ & $\begin{array}{l}0.0221 \\
{[0.021]}\end{array}$ & $\begin{array}{l}-0.0130 \\
{[0.028]}\end{array}$ & $\begin{array}{l}0.0008 \\
{[0.027]}\end{array}$ & $\begin{array}{l}-0.0509 \\
{[0.052]}\end{array}$ & $\begin{array}{l}1.9804^{* * * *} \\
{[0.439]}\end{array}$ & $\begin{array}{l}0.0138 \\
{[0.086]}\end{array}$ \\
\hline $\begin{array}{l}\text { - Years of } \\
\text { Intervention }\end{array}$ & $\begin{array}{l}-0.0380 \\
{[0.182]}\end{array}$ & $\begin{array}{l}-0.0088 \\
{[0.007]}\end{array}$ & $\begin{array}{l}-0.0211^{* * *} \\
{[0.0079]}\end{array}$ & $\begin{array}{l}-0.0289^{* *} \\
{[0.010]}\end{array}$ & $\begin{array}{l}0.0376 \\
{[0.027]}\end{array}$ & $\begin{array}{l}-0.0176 \\
{[0.1509]}\end{array}$ & $\begin{array}{l}0.0301 \\
{[0.036]}\end{array}$ \\
\hline $\begin{array}{l}\text { P-value of Total } \\
\text { Effect of } \\
\text { Intervention }\end{array}$ & 0.7277 & 0.4518 & 0.1389 & 0.1923 & 0.7615 & 0.0000 & 0.4821 \\
\hline $\begin{array}{l}\text { Number of } \\
\text { observations }\end{array}$ & 394 & 496 & 515 & 522 & 522 & 524 & 483 \\
\hline
\end{tabular}

Each column in each panel presents the results of a separate panel regression model. All regressions control for each municipality number of residents (in logs), socio-economic status, average salary for employees (from previous year in logs), percentage of seats of larger party and number of parties (divided by number of legislators), as well as years and municipalities fixed effects. *indicates statistically significant at $10 \%$ level.

indicates statistically significant at $5 \%$ level.

*** indicates statistically significant at $1 \%$ level.

\section{Appendix}

See Appendix Table A1, Table A2, Table A3.

Table A.3

The Marginal Effect of Each Type of Intervention on Municipalities Outcomes of Interest-Including only localities within 7.5 percentage points of Intervention Threshold.

\begin{tabular}{|c|c|c|c|c|c|c|c|}
\hline & \multicolumn{3}{|l|}{ Fiscal Goals } & \multicolumn{4}{|l|}{ Fiscal Tools } \\
\hline & $\begin{array}{l}\text { Log } \\
\text { Deficit per } \\
\text { Capita }\end{array}$ & $\begin{array}{l}\text { Short Term Debt as } \\
\text { Share of Total } \\
\text { Revenue }\end{array}$ & $\begin{array}{l}\text { Log Total } \\
\text { Expenditures } \\
\text { per Capita }\end{array}$ & $\begin{array}{l}\text { Log Total Salary } \\
\text { Payments per } \\
\text { Capita }\end{array}$ & $\begin{array}{l}\text { Log Local Property } \\
\text { Taxes Collected per } \\
\text { Capita }\end{array}$ & $\begin{array}{l}\text { Log Recovery } \\
\text { Payments per } \\
\text { Capita }\end{array}$ & $\begin{array}{l}\text { Log Equalization } \\
\text { Grants per } \\
\text { Capita }\end{array}$ \\
\hline $\begin{array}{l}\text { Effect of Accountant } \\
\text { Intervention }\end{array}$ & $\begin{array}{l}0.3384 \\
{[0.640]}\end{array}$ & $\begin{array}{l}0.0451 \\
{[0.139]}\end{array}$ & $\begin{array}{l}-0.0627^{* *} \\
{[0.045]}\end{array}$ & $\begin{array}{l}-0.0439 \\
{[0.419]}\end{array}$ & $\begin{array}{l}0.0627 \\
{[0.263]}\end{array}$ & $\begin{array}{l}0.5587 \\
{[0.396]}\end{array}$ & $\begin{array}{l}0.1159 \\
{[0.104]}\end{array}$ \\
\hline $\begin{array}{l}\text { Effect of Years of } \\
\text { Accountant } \\
\text { Intervention }\end{array}$ & $\begin{array}{l}-0.0392 \\
{[0.869]}\end{array}$ & $\begin{array}{l}-0.0072 \\
{[0.499]}\end{array}$ & $\begin{array}{l}-0.0252^{* *} \\
{[0.021]}\end{array}$ & $\begin{array}{l}-0.0418^{*} \\
{[0.052]}\end{array}$ & $\begin{array}{l}0.0340 \\
{[0.349]}\end{array}$ & $\begin{array}{l}0.1658 \\
{[0.418]}\end{array}$ & $\begin{array}{l}-0.0009 \\
{[0.966]}\end{array}$ \\
\hline $\begin{array}{l}\text { Effect of Recovery } \\
\text { Program }\end{array}$ & $\begin{array}{l}-0.1584 \\
{[0.806]}\end{array}$ & $\begin{array}{l}-0.0165 \\
{[0.384]}\end{array}$ & $\begin{array}{l}-0.0203 \\
{[0.333]}\end{array}$ & $\begin{array}{l}-0.0075 \\
{[0.625]}\end{array}$ & $\begin{array}{l}-0.0352 \\
{[0.469]}\end{array}$ & $\begin{array}{l}2.0846^{* * *} \\
{[0.000]}\end{array}$ & $\begin{array}{l}-0.0322 \\
{[0.640]}\end{array}$ \\
\hline $\begin{array}{l}\text { Effect of Years of } \\
\text { Recovery Program }\end{array}$ & $\begin{array}{l}0.0267 \\
{[0.925]}\end{array}$ & $\begin{array}{l}0.0020 \\
{[0.818]}\end{array}$ & $\begin{array}{l}0.0215 \\
{[0.249]}\end{array}$ & $\begin{array}{l}0.0181 \\
{[0.237]}\end{array}$ & $\begin{array}{l}-0.0078 \\
{[0.841]}\end{array}$ & $\begin{array}{l}-0.2879^{*} \\
{[0.068]}\end{array}$ & $\begin{array}{l}0.0846 \\
{[0.102]}\end{array}$ \\
\hline $\begin{array}{l}\text { Effect of Summoned } \\
\text { Board }\end{array}$ & $\begin{array}{l}0.4067 \\
{[0.701]}\end{array}$ & $\begin{array}{l}0.1135^{* * *} \\
{[0.001]}\end{array}$ & $\begin{array}{l}-0.0074 \\
{[0.882]}\end{array}$ & $\begin{array}{l}-0.0153 \\
{[0.758]}\end{array}$ & $\begin{array}{l}0.2662^{*} \\
{[0.064]}\end{array}$ & $\begin{array}{l}1.4715^{*} \\
{[0.069]}\end{array}$ & $\begin{array}{l}0.0477 \\
{[0.503]}\end{array}$ \\
\hline
\end{tabular}


Table A.3 (continued)

\begin{tabular}{|c|c|c|c|c|c|c|c|}
\hline & \multicolumn{3}{|l|}{ Fiscal Goals } & \multicolumn{4}{|l|}{ Fiscal Tools } \\
\hline & $\begin{array}{l}\text { Log } \\
\text { Deficit per } \\
\text { Capita }\end{array}$ & $\begin{array}{l}\text { Short Term Debt as } \\
\text { Share of Total } \\
\text { Revenue }\end{array}$ & $\begin{array}{l}\text { Log Total } \\
\text { Expenditures } \\
\text { per Capita }\end{array}$ & $\begin{array}{l}\text { Log Total Salary } \\
\text { Payments per } \\
\text { Capita }\end{array}$ & $\begin{array}{l}\text { Log Local Property } \\
\text { Taxes Collected per } \\
\text { Capita }\end{array}$ & $\begin{array}{l}\text { Log Recovery } \\
\text { Payments per } \\
\text { Capita }\end{array}$ & $\begin{array}{l}\text { Log Equalization } \\
\text { Grants per } \\
\text { Capita }\end{array}$ \\
\hline Effect of Years of & 0.1774 & $-0.0531^{* * *}$ & $-0.0157^{*}$ & -0.0216 & -0.1112 & -0.2971 & 0.0025 \\
\hline Summoned Board & {$[0.568]$} & {$[0.008]$} & {$[0.077]$} & [0.338] & [0.108] & {$[0.415]$} & [0.962] \\
\hline $\begin{array}{l}\text { P-Value of Effect of } \\
\text { Accountant } \\
\text { Intervention }\end{array}$ & 0.5902 & 0.1159 & 0.0110 & 0.0867 & 0.0297 & 0.2137 & 0.0856 \\
\hline $\begin{array}{l}\text { P-Value of Effect of } \\
\text { Recovery Program }\end{array}$ & 0.7876 & 0.3600 & 0.9364 & 0.4801 & 0.2749 & 0.0000 & 0.3364 \\
\hline $\begin{array}{l}\text { P-Value of Effect of } \\
\text { Summoned Board }\end{array}$ & 0.4879 & 0.0448 & 0.6311 & 0.3682 & 0.1284 & 0.1502 & 0.5028 \\
\hline $\begin{array}{l}\text { Number of } \\
\text { observations }\end{array}$ & 319 & 400 & 426 & 425 & 426 & 427 & 392 \\
\hline
\end{tabular}

Each column presents the results of a separate panel regression model. All regressions control for each locality number of residents (in logs), socio-economic status, average salary for employees (from previous year in logs), percentage of seats of larger party and number of parties (divided by number of legislators), as well as years and municipalities fixed effects. P-Value of F-Test of joint effect of interest appears in parentheses below the respective coefficient.

indicates statistically significant at $10 \%$ level,

** indicates statistically significant at $5 \%$ level;

*** indicates statistically significant at $1 \%$ level.

\section{References}

Baskaran, Thushyanthan, Brender, Adi, Blesse, Sebastian, Reingewertz, Yaniv, 2015. Revenue decentralization, central oversight and the political budget cycle: evidence from Israel. Eur. J. Political Econ. http://dx.doi.org/10.1016/j.ejpoleco.2015.12.001 .

Ben-Bassat, Avi, Dahan, Momi, 2012. Social identity and voting behavior. Public Choice 151 (1), 193-214.

Ben-Bassat, Avi, Dahan, Momi, 2009. The crises of localities in Israel: efficiency versus representation. In: Ben-Bassat, A., Dahan, M. (Eds.), The Political Economics of the Municipalities in Israel. The Israel Democracy Institute (in Hebrew), Jerusalem, Israel, pp. 15-91.

Ben-Bassat, Avi, Dahan, Momi, Klor, Esteban F., 2013. Representativeness and Efficiency in Local Government. The Israel Democracy Institute (in Hebrew), Jerusalem, Israel.

Bertrand, Marianne, Duflo, Esther, Mullainathan, Sendhil, 2004. How much should we trust differences-in-differences estimates? Q. J. Econ. 119 (1), $249-275$.

Besley, Timothy, Case, Anne, 1995. Incumbent behavior: vote-seeking, tax-setting, and yardstick competition. Am. Econ. Rev. 85 (1), $25-45$.

Bird, Richard M., Tassonyi, Almos, 2003. Constraining subnational fiscal behavior in Canada: different approaches, similar results? In: Rodden, J., Eskeland, G.S., Litvack, J. (Eds.), Fiscal Decentralization and the Challenge of Hard Budget Constraints. The MIT Press, Cambridge, Massachusetts, pp. 85-132

Blanchard, Olivier, Shleifer, Andrei, 2001. Federalism with and without political centralization: China versus Russia. IMF Staff Pap. 48 (4), 171-179.

Bordignon, Massimo, 2013. Economic crisis and recentralization of government: the Italian experience. IEB'S. Report. Fisc. Fed. 62-67.

Bordignon, Massimo, Turati, Gilberto, 2009. Bailing out expectations and public health expenditures. J. Health Econ. 28 (2), $305-321$.

Brender, Adi, 2003. The effect of fiscal performance on local government election results in Israel: 1989-1998. J. Public Econ. 87 (9-10), $2187-2205$.

Dietrichson, Jens, Ellegård, Lina Maria, 2015. Assist or desist? Conditional bailouts and fiscal discipline in local governments. Eur. J. Political Econ. 38 (June), $153-168$.

Enikolopov, Ruben, Zhuravskaya, Ekaterina, 2007. Decentralization and political institutions. J. Public Econ. 91 (11-12), 2261-2290.

Inman, Robert P., 2003. Transfers and bailouts: enforcing local fiscal discipline with lessons from the U.S. federalism. In: Rodden, J., Eskeland, G.S., Litvack, J. (Eds.), Fiscal Decentralization and the Challenge of Hard Budget Constraints, Cambridge, Massachussetts. The MIT Press, Cambridge, MA, pp. $35-83$.

Klor, Esteban F., 2006. A positive model of overlapping income taxation in a federation of states. J. Public Econ. 90 (4-5), 703-723.

Kornai, Janos, 1979. Resource-constrained versus demand-constrained systems. Econometrica 47 (4), 801-819.

Kornai, Janos, Maskin, Eric, Roland, Gerard, 2003. Understanding the soft budget constraint. J. Econ. Lit. 41 (4), $1095-1136$.

McCarten, William J., 2003. The challenge of fiscal discipline in the Indian States. In: Rodden, J., Eskeland, G.S., Litvack, J. (Eds.), Fiscal Decentralization and the Challenge of Hard Budget Constraints. The MIT Press, Cambridge, Massachusetts, pp. 249-286.

Oates, Wallace E., 1972. Fiscal Federalism. Harcourt, New York .

Pettersson-Lidbom, Per, 2010. Dynamic commitment and the soft budget constraint: an empirical test. Am. Econ. J.: Econ. Policy 2 (3), 154-179.

Prud'homme, R.émy, 1995. On the dangers of decentralization. World Bank Res. Obs. 10 (2), 201-220.

Quian, Yingyi, Gérard, Roland, 1998. Federalism and the soft budget constraint. Am. Econ. Rev. 88 (5), 1143-1162.

Rattsø, J.ørn, 2003. Vertical imbalance and fiscal behavior in a welfare state: Norway. In: Rodden, J., Eskeland, G.S., Litvack, J. (Eds.), Fiscal Decentralization and the Challenge of Hard Budget Constraints. The MIT Press, Cambridge, Massachusetts, pp. 133-160.

Reingewertz, Yaniv, 2010. Political Competition, Ethnic Fragmentation and Fiscal Status: Evidence from Municipalities in Israel. The Hebrew University of Jerusalem Unpublished Manuscript.

Reingewertz, Yaniv, 2012. Do municipal amalgamations work? Evidence from municipalities in Israel. J. Urban Econ. 72 (2-3), $240-251$.

Rodden, Jonathan A., 2006. Hamilton's Paradox: The Promise and Peril of Fiscal Federalism. Cambridge University Press, Cambridge .

Rodden, Jonathan A., 2002. The dilemma of fiscal federalism: grants and fiscal performance around the world. Am. J. Political Sci. 46 (3), $670-687$.

Rosenberg, Jacob, 1992. Rationality and the political business cycle: the case of local government. Public Choice 73 (1), $71-81$.

Sorribas-Navarro, Pilar, 2011. Bailouts in a fiscal federal system: evidence from Spain. Eur. J. Political Econ. 27 (1), $154-170$.

Tanzi, Vito, 1996. Fiscal federalism and decentralization: a review of some efficiency and macroeconomic aspects. In: Bruno, M., Pleskovic, B. (Eds.), Annual World Bank Conference on Development Economics. World Bank, Washington D.C .

Charles, Tiebout, 1956. A pure theory of local expenditures. J. Political Econ. 64 (5), 416-424.

Turner, David, Whitman, Philip, 2005. Learning from the experience of recovery: the turnaround of poorly performing local authorities. Local Gov. Stud. 31 (5), $627-654$.

Pi-Sunyer, Viver, Carles, Martín, Gerard, 2013. The Recentralization process of state autonomies. IEB's Report on Fiscal Federalismpp. 46-61.

Webb, Stephen, 2003. Argentina: hardening the provincial budget constraint. In: Rodden, J., Eskeland, G.S., Litvack, J. (Eds.), Fiscal Decentralization and the Challenge of Hard Budget Constraints. The MIT Press, Cambridge, Massachusetts, pp. 189-211.

Wetzel, Deborah, Papp, Anita, 2003. Strengthening hard budget constraints in Hungary. In: Rodden, J., Eskeland, G.S., Litvack, J. (Eds.), Fiscal Decentralization and the Challenge of Hard Budget Constraints. The MIT Press, Cambridge, Massachusetts, pp. 393-427.

Yee, Albert S., 2012. China's macroeconomic response to the global recession: ideational sources and substantive contents. Asian Perspect. 36 (1), 1-42. 
Ekaterina Zhuravskaya. 2010. Federalism in Russia CEFIR/NES Work. Pap. No 141.

Abadie, Alberto, Gardeazabal, Javier, 2003. The economic costs of conflict: A case study of the Basque Country. Am. Econ. Rev 93 (1), 113-132.

Abadie, Alberto, Diamond, Alexis, Hainmueller, Jens, 2010. Synthetic control methods for comparative case studies of aggregate interventions: Estimating the effect of California's tobacco control programs. J. Am. Stat. Assoc. 105 (490), 493-505. 